
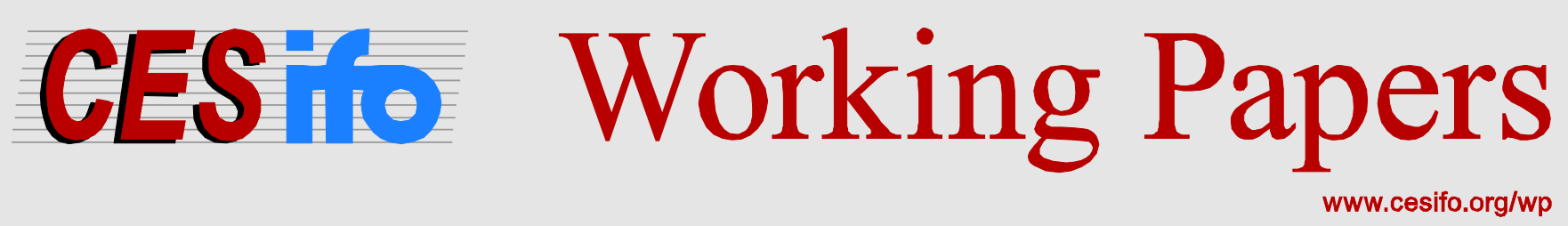

\title{
Private Debt Overhang and the Government Spending Multiplier: Evidence for the United States
}

\author{
Marco Bernardini \\ Gert Peersman
}

\author{
CESIFO WORKING PAPER NO. 5284 \\ CATEGORY 6: FisCAL POLICY, MACROECONOMICS AND GROWTH \\ MARCH 2015
}

An electronic version of the paper may be downloaded

- from the SSRN website:

- from the RePEc website:

- from the CESifo website:

wWw.SSRN.com

Www.RePEc.org

www.CESifo-group.org/wp 


\title{
Private Debt Overhang and the Government Spending Multiplier: Evidence for the United States
}

\begin{abstract}
Using state-dependent local projection methods and historical U.S. data, we find that government spending multipliers are considerably larger in periods of private debt overhang. In particular, we find significant crowding-out of personal consumption and investment in lowdebt states, resulting in multipliers that are significantly below one. Conversely, in periods of private debt overhang, there is a strong crowding-in effect, while multipliers are much larger than one. In high-debt states, more (less) government purchases also reduce (increase) the government debt-to-GDP ratio. These results are robust for the type of government spending shocks, and when we control for the business cycle, government debt overhang and the zero lower bound on the nominal interest rate. Our findings imply that spending multipliers were likely much larger than average during the Great Recession.
\end{abstract}

JEL-Code: C320, E320, E620, N120.

Keywords: government spending multipliers, drivers, private debt.

Marco Bernardini

Department of Financial Economics

Ghent University

W. Wilsonplein $5 D$

Belgium - 9000 Gent

marco.bernardini@ugent.be
Gert Peersman

Department of Financial Economics

Ghent University

W. Wilsonplein $5 D$

Belgium - 9000 Gent

gert.peersman@ugent.be

This version: February 2015

We thank Karel Mertens, participants at the "Belgian Macroeconomics Workshop" and the Deutsche Bundesbank "Workshop on Macroeconomic Applications of Time Series Methods" for useful comments and suggestions. All remaining errors are ours. 


\section{Introduction}

The Great Recession and the European sovereign debt crisis have reignited the academic and political debate on the role of fiscal stimulus packages for business cycle stabilization, as well as the macroeconomic consequences of austerity policies. Whereas the debate previously focused mainly on the average size of the so-called government spending multiplier, i.e. the dollar response of output to an exogenous dollar increase or decrease in government purchases, the current debate centers more on the question whether government spending multipliers differ according to the state of the economy. In particular, government spending multipliers are not structural constants, and may depend on a number of conditions that vary across countries and time (Hall 2009). From a theoretical perspective, multipliers depend for instance on monetary policy and the amount of slack in the economy. Eggertsson (2011), Eggertsson and Woodford (2003) and Christiano et al. (2011) show that a deficit-financed increase in government purchases has a much stronger impact on economic activity when the nominal interest rate hits the zero lower bound. Michaillat (2014) demonstrates that the effect of government policies may be stronger in recessionary periods, even when the zero lower bound does not bind.

The empirical support for both hypotheses is, however, mixed. For example, Auerbach and Gorodnichenko $(2012,2013)$ find innovations to government purchases to be much more effective in recessions than expansions, but this finding cannot be confirmed by Owyang et al. (2013) and Ramey and Zubairy (2014) for military spending news shocks over a longer sample period. The latter study also finds no robust evidence that multipliers are greater when interest rates are near the zero lower bound. Accordingly, Ramey and Zubairy conclude that "...contrary to recent conjecture, government spending multipliers were not necessarily higher than average during the Great Recession."

It is widely believed that a rapid increase in household debt between 2000 and 2008 set the stage for the Great Recession and that tightening household borrowing constraints have been essential for understanding the macroeconomic consequences of the crisis (e.g. Hall 2011). In this context, it is surprising that the role of private debt has so far been ignored in the empirical analysis on fiscal multipliers. Indeed, Eggertsson and Krugman (2012) demonstrate theoretically that the size of the government spending multiplier increases in situations in which an overhang of debt forces some debt-constrained agents to deleverage. Also Perotti (1999) and Galí et al. (2007) show that the spending multi- 
plier rises with the amount of households that cannot or do not maximize lifetime utility due to, for instance, borrowing constraints. Intuitively, in the standard Neoclassical and New-Keynesian model, deficit-financed increases in government purchases generate a negative wealth effect that induces a reduction in consumption of intertemporal maximizing households. This crowding-out effect of government spending vanishes for households that do not participate in the financial market or have no access to intertemporal substitution, resulting in traditional Keynesian-type multipliers in which consumption is based on disposable income rather than permanent income. Combined with sticky prices, this results in a higher average marginal propensity to consume and hence a greater multiplier. More generally, drawing on ideas back to Fisher (1933), numerous studies have shown that borrowers' balance sheet conditions and the amount of debt in the economy are crucial for the propagation and amplification of shocks and policy interventions. ${ }^{1}$ It is an open question whether debt also matters for the effects of fiscal policy, in particular the size of fiscal multipliers.

In this paper, we provide formal evidence on the influence of private debt overhang on government spending multipliers. More specifically, in the spirit of Auerbach and Gorodnichenko (2013), Owyang et al. (2013) and Ramey and Zubairy (2014), we estimate state-dependent government purchases multipliers for the United States using Jordà's (2005) local projection method, and allow the state of the economy to vary according to the presence of debt overhang in the (nonfinancial) private sector. High-debt and low-debt states are identified as periods when private debt-to-income ratios were respectively above and below trend. We use historical data from Gordon and Krenn (2010) and Carter et al. (2006) to have sufficient episodes of substantial variations in government spending and private debt states, i.e. the sample period of the local projections is 1928Q1-2013Q4. For example, the fluctuations in government purchases and private debt during the Great Depression and World War II were huge, providing a rich source of information to analyze the role of debt overhang as a driver of the spending multiplier. We examine the effects

\footnotetext{
${ }^{1}$ For example, Mishkin (1978) and Bernanke (1983) argue that the weakness of borrowers' balance sheets has contributed to the severity of the Great Depression. Bernanke and Gertler (1989) show how fluctuations in the net worth of borrowers could serve as an accelerator of the business cycle. There is also a growing empirical literature documenting an important role of private debt for macroeconomic fluctuations. For example, Mian and Sufi (2011) find that differences in the debt overhang of households before the crisis can explain the post-crisis recovery at the county level within the United States, whereas Jordà et al. (2013) find that more credit-intensive asset prices bubbles tend to be followed by deeper recessions and slower recoveries for a panel of 14 advanced countries between 1870 and 2008 .
} 
of two very different types of government spending shocks that have been proposed in the literature. In particular, we consider Ramey's (2011a) narrative defense news shocks, and unanticipated changes in government purchases obtained from a VAR model with time-varying parameters in the spirit of Blanchard and Perotti (2002).

We find that government spending multipliers are considerably larger in periods of private debt overhang. Specifically, the results reveal a significant crowding-out effect on real personal consumption and investment in low-debt states, resulting in multipliers that are significantly below one. Conversely, in high-debt states, both consumption and investment increase in response to an expansionary government spending shock, whereas multipliers turn out to be much larger than one. At some horizons, we even find values above three. Furthermore, in the identified periods of private debt overhang over the past century, more (less) government purchases have on average reduced (increased) the government debt-to-GDP ratio.

The results are robust for alternative specifications of the model, definition of debt overhang, a shorter (post-WWII) sample period, and the type of government spending shocks. Moreover, the results prove to be robust when we control for the business cycle, the zero lower bound on the nominal interest rate and government debt overhang. The latter is done by estimating "augmented" state-dependent local projection models. Noteworthy, by controlling for the presence of private debt overhang, the state of the business cycle and the zero lower bound do not seem to matter much for the size of the multiplier. For government debt, we find evidence that the multiplier decreases in periods when government debt is above trend, but this result only holds for the spending shock obtained from the TVPVAR model, while the magnitude of the impact is modest compared to the role of private debt overhang.

These stylized facts have some important (policy) implications. First, the amount of private debt in the economy seems to be an important indicator for the repercussions of fiscal consolidations and stimulus packages. In low-debt periods, increases in government purchases may not be effective in stimulating private sector activity, while the consequences of fiscal consolidations are probably not very harmful. In contrast, at times of debt overhang in the private sector, or periods when highly indebted private sector agents repair their balance sheets, deficit-financed government spending is probably able to support the economy. In other words, as argued by Eggertsson and Krugman (2012), more public debt can be a solution to a problem caused by too much private debt. A fiscal expansion 
could sustain output and employment while private balance sheets are repaired, and the government can successfully pay down its own debt after the deleveraging period has come to an end.

Second, given the excessive private debt levels at the onset of the Great Recession, our findings align with the emerging post-crisis perception that purchase multipliers were much larger than in normal times. In particular, the private debt overhang in some euro area countries has presumably enhanced the consequences of the large-scale fiscal consolidations by some of the governments, contributing to the recession in the aftermath of the sovereign debt crisis, a conclusion which is consistent with the analysis of Blanchard and Leigh (2013). As a matter of fact, according to the estimated parameters for the United States, the euro area government debt-to-GDP ratios might even have increased because of the consolidations programs. Finally, theoretical macroeconomic models that analyze fiscal policy issues should take into account debt overhang in the private sector to properly capture the interaction with the real economy. More generally, debt seems to matter for macroeconomic fluctuations.

The rest of the paper is organized as follows. In the next section, we describe the statedependent local projection methodology. The measurement of private debt states and different types of government spending shocks that we consider in the empirical analysis are discussed in section 3. The benchmark estimation results are reported in section 4, the impact on some other relevant variables in section 5, while section 6 addresses some extensions of the model to control for the influence of the business cycle, the zero lower bound on the nominal interest rate, and the amount of government debt. Finally, section 7 concludes.

\section{Methodology}

To investigate government spending multipliers depending on the state of the economy, we follow Auerbach and Gorodnichenko (2013), Owyang et al. (2013) and Ramey and Zubairy (2014), and estimate state-dependent impulse responses to exogenous innovations in government purchases using Jordà's (2005) local projections method. This method has become very popular to estimate fiscal multipliers. The advantages compared to vector autoregressions (VARs) is that it is more robust to misspecification because it does not impose implicit dynamic restrictions on the shape of the impulse responses, while also 
a more parsimonious specification can be used since not all variables are required to be included in all equations. Moreover, it can easily accommodate state dependence and avoids a potential bias when elasticities are converted to multipliers. ${ }^{2}$

For each variable, and each horizon, we estimate the following linear regression model:

$$
\begin{aligned}
z_{t+h}= & I_{t-1}\left[\alpha_{A, h}+\psi_{A, h}(L) y_{t-1}+\beta_{A, h} \text { shock }_{t}\right]+ \\
& \left(1-I_{t-1}\right)\left[\alpha_{B, h}+\psi_{B, h}(L) y_{t-1}+\beta_{B, h} \text { shock }_{t}\right]+\text { trend }^{2}+\varepsilon_{t+h}
\end{aligned}
$$

where $z$ is the variable of interest at horizon $h, I_{t-1}$ is a dummy variable that indicates the state $\{A, B\}$ of the economy at the moment of the government spending shock shock, $y$ is a vector of control variables, $L$ represents the lag operator, and trend ${ }^{2}$ a linear and a quadratic time trend. The collection of the $\beta_{A, h}$ and $\beta_{B, h}$ coefficients provide directly the state-dependent responses of variable $z$ at time $t+h$ to the shock at time $t$.

The variables $z$ that we consider in the estimations are real per capita GDP, personal consumption expenditures, investment and government purchases. ${ }^{3}$ From 1947Q1 onwards, we use the National Income and Product Accounts (NIPA) Tables from the Bureau of Economic Analysis. Before this period, i.e. 1919Q1-1946Q4, we use the Gordon and Krenn (2010) historical quarterly dataset. ${ }^{4}$ Following Hall (2009) and Barro and Redlick (2011), we convert GDP and its components, including government purchases, before the estimations as follows:

$$
z_{t+h}=\frac{X_{t+h}-X_{t-1}}{Y_{t-1}}
$$

where $Y$ is real GDP, and $X$ respectively real GDP, government purchases, personal consumption and investment. Accordingly, all coefficients are in the same units, which is needed for the construction of the multipliers. The control variables $y$ are the log differences of real GDP, government purchases, personal consumption and investment,

\footnotetext{
${ }^{2}$ Notice that this method also has some disadvantages to calculate impulse responses, in particular a more erratic pattern at longer horizons because of a loss of efficiency. For a discussion, we refer to Ramey and Zubairy (2014).

${ }^{3}$ In section 5, we also estimate the effects on the average marginal tax rate constructed by Barro and Redlick (2011), the nominal interest rate, the private debt-to-GDP ratio, and the government debt-to-GDP ratio to learn more about the macroeconomic dynamics.

${ }^{4}$ Similar to Perotti (2008), we use respectively fixed investments and personal consumption expenditures related to non-durable goods and services. Changes in respectively inventories and durable goods are thus excluded. For more details on the construction of all data used in this paper, we refer to the data appendix.
} 
whereas $L=8$ in all the estimations. ${ }^{5}$ For the definition of the government purchases shocks and the state of the economy, we refer to the next section.

\section{Measuring private debt states and government spending shocks}

To analyze whether government spending multipliers depend on the presence of private debt overhang in the economy, we need to identify high and low private debt states. Furthermore, for the estimation of fiscal multipliers, it is crucial to identify exogenous and unanticipated innovations to government purchases. In this section, we describe how we disentangle both states of the economy, and how we derive autonomous shifts in government purchases.

\subsection{Private debt states}

The identification of episodes of private debt overhang is not trivial. It essentially requires two choices: the selection of a private debt indicator that is available for the whole sample period, and a threshold criterion to disentangle high-debt and low-debt periods. For the benchmark estimations, we use the domestic nonfinancial private debt-to-GDP ratio as the debt indicator, i.e. domestic debt net of government and financial sector debt divided by national income. A similar indicator is used by Schularick and Taylor (2012) to identify (bank) credit booms. The advantage of using a debt-to-GDP ratio is that we control for inflation, population and, above all, economic activity. The quarterly series is constructed by splicing the most recent FED flow of funds data to the historical records provided in Carter et al. (2006). ${ }^{6}$ To disentangle high-debt and low-debt states, we define the former as the periods when there was a positive deviation of the debt-to-GDP ratio from a very smooth Hodrick-Prescott trend (i.e. $\lambda=1,000,000$ ), and the latter as the periods when the debt-to-GDP ratio was below its long-term trend. The debt-to-GDP ratio, the HP trend and the resulting dummy variable are shown in panel (a) of Figure 1. This

\footnotetext{
${ }^{5}$ The conclusions reported in this paper are not sensitive to the set and transformation (first differences versus levels) of the control variables, the number of lags, as well as the dimension of the trend. These results are available upon request.

${ }^{6}$ In the appendix, we provide all the data transformations, together with the abbreviations of the official sources.
} 
relative simple procedure unambiguously identifies four periods of private debt overhang: 1930Q3-1940Q2, 1956Q1-1975Q3, 1985Q3-1992Q1 and 2001Q4-2010Q3. Overall, the U.S. economy has been about half of the time in each state, which is convenient for an accurate estimation of the parameters.

As a robustness check, we have also considered some alternative measures to define periods of private debt overhang. More specifically, in panels (b)-(d) of Figure 1, we show the identification of high-debt and low-debt states when we apply an extreme smooth HP-filter $(\lambda=10,000,000)$, when we use the total private debt-to-GDP ratio (including financial sector debt), or only household debt-to-GDP. The latter is, for instance, used by Krugman (2013) as a proxy for the debt burden of households. Finally, in line with Goodhart and Hofmann (2008) their criterion to identify house prices booms, panel (e) of Figure 1 shows periods of debt overhang defined as a positive deviation of real (nonfinancial sector) debt per capita from a smooth HP trend $(\lambda=1,000,000)$ of more than 5 percent lasting at least 8 quarters. As can be seen in the figure, all these measures more or less identify the same periods as high-debt and low-debt states. The differences are somewhat larger for the latter criterion. Given the similarities amongst the indicators, we are confident that we have a reasonable proxy to identify periods of private debt overhang. In the rest of the paper, we only report the results for the benchmark indicator. For the estimations based on the alternative measures, we refer to the on-line appendix of the paper. The conclusions prove to be robust for the selection of the indicator.

\subsection{Government spending shocks}

There is not a unique way to identify exogenous changes in government purchases. Numerous studies have been conducted to isolate such components in government spending, and none of them are immune to identification problems. In this paper, we do not take a stance on the best way to identify shocks to government purchases, and consider the two most popular approaches that have been used in the literature.

Defense news As a first measure of unanticipated innovations to government purchases, we use Ramey's (2011a) narrative defense news variable reflecting changes in the expected present value of government spending that are linked to political and military events, which has been updated and extended by Owyang et al. (2013) and Ramey and Zubairy (2014). The variable has been constructed using Business Week and several newspaper sources. 
The time series of the shocks, i.e. the nominal present value of expected government spending divided by one-quarter lag of nominal GDP, is shown in the top panel of Figure 2. These changes are likely to be independent of the state of the economy, and can be considered as exogenous shocks to government spending.

The dynamic effects of the defense news shocks across all states (i.e. the linear case) are shown in Figure 3, which could serve as a benchmark for the state-dependent results reported in the next section. The panels show the responses of respectively real government spending, GDP, personal consumption and investment for the first twelve quarters after the shocks, together with 90 percent confidence bands that are based on Newey-West standard errors. ${ }^{7}$ Table 1 reports the (cumulative) output multipliers after one, two and three years. These are calculated as $\frac{\sum_{h=1}^{H} \Delta Y_{i}}{\sum_{h=1}^{H} \Delta G_{i}}$, where $H$ is the horizon of the multiplier, and $\Delta$ the difference between the path conditional on the shock versus no shock. The linear results are similar to Ramey (2011a) and Ramey and Zubairy (2014). A news shock equal to $1 \%$ of GDP raises government spending and GDP, while there is a decline in personal consumption and investment. The corresponding multipliers are below one at all horizons (Table 1), but not always significantly different from one.

A drawback of the defense news shocks is that it cannot be excluded that the political and military events could have had an impact on the economy beyond the changes in government purchases, and that other fiscal shocks might have occurred at the same time, distorting the estimation results. Moreover, Perotti (2013) shows that the estimated average multipliers based on the defense news shocks are sensitive to the presence of some extreme military events in the sample period, and that multipliers differ between defense and nondefense government spending on goods and services. For this reason, it is useful to also consider an alternative measure of government spending shocks.

Recursively identified TVP-VAR Since the seminal paper of Blanchard and Perotti (2002), several studies have used VAR models to identify government spending shocks. They key identifying assumption that is usually made in this literature is that it typically takes longer than a quarter for discretionary fiscal policy to respond to changes in the economy, i.e. there is a decision lag. For the second measure of government spending shocks, we make the same assumption to achieve identification. A drawback of this

\footnotetext{
${ }^{7}$ More specifically, we have estimated a linear version of equation (1): $z_{t+h}=\alpha_{h}+\psi_{h}(L) y_{t-1}+$ $\beta_{h}$ shock $_{t}+$ trend $^{2}+\varepsilon_{t+h}$.
} 
approach is that there is evidence that such shocks are predictable, and hence not fully unanticipated. ${ }^{8}$ Another issue when using VARs to identify government spending shocks over a long sample period, containing several changes in the structure of the economy and the volatility of the shocks, is that the assumption of constant parameters is not appropriate and could bias the results. For this reason, we derive the shocks from a VAR model with time-varying parameters.

More specifically, we use the estimated government spending shocks from Bernardini and Peersman (2015). In Bernardini and Peersman (2015), we have estimated a quarterly Bayesian VAR model in the spirit of Blanchard and Perotti (2002), where the parameters and volatility of the shocks are allowed to vary over time according to a stochastic process. In essence, the identified shocks are innovations to government purchases obtained from a time-varying government spending rule, where the parameters of the rule and variance of the innovations could change over time according to a random-walk process. ${ }^{9}$ This is a very different approach as Ramey (2011a), and thus an excellent way to assess the robustness of the results. The time series of the shocks, measured as $\frac{G_{t}-G_{t-1}}{Y_{t-1}}$, is shown in the bottom panel of Figure 2. ${ }^{10}$ As can be seen, the volatility of the shocks has been much higher before the end of WWII, which confirms that the estimation of a constant parameters VAR model over the whole sample period would not have been appropriate. The linear effects and multipliers of the identified government spending shocks can respectively be found at the bottom of Figure 3 and in the right column of Table 1. In line with the defense news shocks, we find crowding-out of personal consumption and investment, resulting in multipliers that are below one. ${ }^{11}$

\footnotetext{
${ }^{8}$ Ramey (2011a) finds that professional forecasts and her narrative indicator Granger-cause the VAR shocks. However, Mertens and Ravn (2010) and Perotti (2014) show that the predictability of the VAR innovations does not significantly affect the results.

${ }^{9}$ The variables included in the VAR are the log first differences of real per capita government purchases, GDP, investment and personal consumption expenditures. The structural shocks are identified by imposing a Cholesky structure, where government purchases are ordered as the first variable. In that study, we find sizable time-variation in the government spending multiplier, including much higher multipliers in the Great Depression and the Great Recession, but it is not possible to formally identify the exact reason of the time-variation.

${ }^{10}$ Given that the Gordon and Krenn (2010) data for real GDP, personal consumption and investment start in 1919Q1, and the training sample we had to use to generate the priors of the TVP-VAR, the sample period of the local projections in this paper is 1928Q1-2013Q4.

${ }^{11}$ For personal consumption, we obtain a positive effect for a sample period starting in 1947Q1, a finding which is consistent with most post-WWII VAR estimations.
} 


\section{Are government spending multipliers greater in periods of private debt overhang?}

The benchmark state-dependent estimation results for the defense news and TVP-VAR shocks are presented in respectively Figure 4 and 5 . The panels now show the responses of real government spending, GDP, personal consumption and investment in both states for the first twelve quarters after the shocks, together with 90 percent confidence bands that are based on Newey-West standard errors. There is a significant increase of government spending and output after both shocks in both states, but the pattern is different. For the defense news shocks, the rise in government spending and output is much larger and more persistent in high-debt states than in low-debt states. For the TVP-VAR shocks, in contrast, the surge in government purchases is more subdued and short-lived in the high-debt state relative to the low-debt state. Despite the different nature and pattern of both spending shocks, the corresponding multipliers, which are reported in Table 2, are remarkably similar. As can be seen in the table, the government spending multipliers are considerably larger in high-debt periods. The size of the difference is economically meaningful. For both shocks, we find multipliers that are positive, but significantly smaller than one in low-debt states. In contrast, the estimated multipliers in periods of debt overhang are significantly greater than one, and even reach values that are above three. ${ }^{12}$ Noteworthy, the multipliers in low-debt states are close to the linear estimates, despite the fact that both states cover about half of the sample period. This implies that linear multipliers could be misleading as a proxy for the average impact.

A closer inspection of the responses of personal consumption and investment in the bottom panels of Figure 4 and 5, reveals the reason for the different multipliers in both states. In particular, we find a significant decline of personal consumption and investment for both shocks in periods when private debt is below its long-term trend. In other words, there are crowding-out effects of government purchases, which is consistent with intertemporal optimizing households in Neoclassical and several New-Keynesian models. However, exactly the opposite is the case in periods of debt overhang. We systematically

\footnotetext{
${ }^{12}$ Some studies only report the impact multipliers of innovations to government spending (for "news" shocks, the impact multiplier is obviously not very informative). For the TVP-VAR, we find impact multipliers of 1.45 and 0.93 in respectively the high-debt and low-debt state. The former is significantly different from one, the latter not. The difference between the impact multipliers $(0.52)$ is statistically significant.
} 
find a rise of personal consumption and investment after an expansionary government spending shock, a result that is more in line with traditional Keynesian reasoning. In sum, the amount of private debt in the economy seems to be a crucial indicator for the repercussions of fiscal stimulus and consolidation programs.

As already mentioned in section 3 , and shown in the online appendix of the paper, the results are robust when we use alternative debt indicators to determine the states. Most studies typically report fiscal multipliers for the post-WWII sample period, an era which is characterized by less volatile government purchases shocks. Moreover, since our benchmark multipliers are estimated over a sample period that combines two sources of data (Gordon and Krenn database before, and NIPA Tables after 1947Q1), we have also re-estimated the state-dependent local projections solely for the post-1947 period as a robustness check. The results are summarized in Figure 6 and Table 3, and confirm the conclusions obtained from the whole sample period. Specifically, the estimated multipliers are much higher, and most of the time significantly larger than one in periods of ample private debt, while there are crowding-out effects in low-debt states. For the defense news shocks, the multipliers are even not significantly different from zero in the low-debt state. Overall, the estimated magnitudes of the multipliers are lower in both states in the shorter sample period, and the confidence intervals for the responses of personal consumption are wider, but they qualitatively confirm the benchmark results.

\section{Effects on the interest rate, tax rate and debt ratios}

Although our approach cannot determine the exact reason for the different behavior in both states, an issue which is out of the scope of this paper, we have also estimated the state-dependent effects of government spending shocks on some other variables to learn more about the macroeconomic dynamics. The results of this exercise are shown in Figure 7. More precisely, the panels in the figure present the impact of the shocks on respectively the nominal interest rate, the average marginal tax rate, as well as the private and government debt-to-GDP ratios. ${ }^{13}$ A number of interesting observations can be made. First, the nominal interest rate response is negligible and almost never significant. In the

\footnotetext{
${ }^{13}$ For the nominal interest rate and the marginal tax rate, we have included the lags of both variables instead of consumption and investment as control variables in equation (1). The same applies for the private and government debt-to-GDP ratios.
} 
low-debt state, there is even a mild decline following an expansionary spending shock. A passive or accommodative monetary policy reaction is typically also found in other empirical studies (e.g. Ramey 2011a; Perotti 2014). This suggests that the presence of the zero lower bound on the nominal interest rate, i.e. the inability of the central bank to change the interest rate in response to fiscal policy, is by itself not a unique situation. Also in other periods, the interest rate seems to have remained constant after spending shocks.

Second, as pointed out by Baxter and King (1993), the way how the increases in government spending are financed might matter for the macroeconomic consequences. Multipliers are expected to be lower when spending is financed by distortionary taxes, rather than deficits. The estimated state-dependent responses of the marginal tax rate, however, suggest that the different estimated multipliers in high and low private debt states are not driven by the way spending is financed. In particular, the response of the marginal tax rate is not significantly different in both states for the TVP-VAR government purchases shocks. For the defense news shocks, taking into account the pattern of government spending, the tax rate increases even relatively more in the high-debt state.

The effects of the government spending shocks on private and government debt ratios provide some useful insights on the effectiveness of fiscal consolidations and the macroeconomic dynamics in both states. ${ }^{14}$ For both shocks, we observe a decline in the private debt-to-GDP ratio after expansionary spending shocks. For the defense news shocks, this is permanent. For the TVP-VAR shocks, the decline is temporary. More importantly, the reduction in private debt ratios is for both shocks considerably larger in high-debt states. This finding is by itself not a surprise, given the greater multiplier, but the stronger decline in the private debt ratio could also serve as an amplifier of the government purchases shocks. Specifically, expansionary government spending shocks improve the balance sheets of households and firms more in high-debt states, making several of them less debtconstrained, which could in turn stimulate consumption and investment, further reducing the debt burden, etc. The opposite is obviously the case for a restrictive fiscal policy shock. This is exactly the debt deflation (inflation) amplification described in Fischer (1933) and Eggertsson and Krugman (2012). Such a mechanism, which could amplify the differences

\footnotetext{
${ }^{14}$ As can be seen in the on-line appendix, the results for the government debt-to-GDP ratio are not robust for some of the alternative measures to identify private debt states. Furthermore, the response of the private debt-to-GDP ratio is not significantly different in both states for the post-1947 sample period.
} 
across private debt states, is also consistent with Mian and Sufi (2014), who observe that the marginal propensity to consume out of wealth is much higher for highly-leveraged households.

The results also reveal that government debt consolidations via a reduction in expenditures were not effective in reducing government debt in periods of debt overhang in the private sector. In contrast, fiscal expansions have on average reduced government debt in high-debt states. As shown in Figure 7, expansionary (restrictive) shocks to government purchases tend to be followed by a decline (rise) in the government debt-to-GDP ratio in high-debt states for the TVP-VAR shocks, whereas the opposite is true in low-debt states. Put differently, the permanent income of (intertemporal maximizing) Ricardian agents does not decrease after an expansionary fiscal policy shock in high-debt states. Since government debt does not increase, there is also no rise in future tax liabilities created by the government purchases. Hence, Ricardian agents probably do not cut consumption in high-debt states. In contrast, they might even increase consumption, further reinforcing the government spending shock. In sum, the stronger effect on private debt in high-debt states, as well as the favorable effect of a positive spending shock on government debt, could have acted as an accelerator mechanism for government purchases. For defense news shocks, there is also a decrease (increase) of the government debt-to-GDP ratio the first five quarters after the shocks in periods of debt overhang. However, the sign becomes positive (negative) after about two years, while the effect in low-debt states is insignificant.

\section{The role of other prominent state variables}

So far, following the state-dependent local projections and regime-switching VAR literature, we have allowed the economy to switch between two alternative states, where the states are defined as periods of respectively high and low private debt overhang. In this section, we relax this assumption by estimating "augmented" state-dependent local projection models. By doing this, we are able to assess whether our results still hold when we control for other potential states of the economy that could have had an influence on the government spending multiplier. For example, there could have been an overlap of high-debt states with recessions or periods when the nominal interest rate reached the zero lower bound. In particular, there exists a literature which argues that these features also augment the multiplier. We first describe the augmented state-dependent local projection 
model that we use, and then discuss the estimation results when we control for respectively the business cycle, the zero lower bound on the nominal interest rate, and the amount of government debt overhang.

\subsection{Augmented state-dependent local projection model}

For each variable, and each horizon, we estimate the following linear regression model: ${ }^{15}$

$$
\begin{aligned}
z_{t+h}= & \alpha_{A, h}+\psi_{A, h}(L) y_{t-1}+\beta_{A, h} \text { shock }_{t}+ \\
& I_{B, t-1}\left[\alpha_{B, h}+\psi_{B, h}(L) y_{t-1}+\beta_{B, h} \text { shock }_{t}\right]+ \\
& I_{C, t-1}\left[\alpha_{C, h}+\psi_{C, h}(L) y_{t-1}+\beta_{C, h} \text { shock }_{t}\right]+\text { trend }^{2}+\varepsilon_{t+h}
\end{aligned}
$$

where the notations are essentially the same as in the benchmark model. However, $I_{B, t-1}$ is now a dummy variable for being in a high-debt state, whereas $I_{C, t-1}$ is a dummy indicator for the control state variable (e.g. recessionary periods). Notice that the state-dependent responses (controlling for the other state variable) are respectively the sum of the coefficients $\beta_{A, h}+\beta_{B, h}$ and $\beta_{A, h}+\beta_{C, h}$, while $\beta_{A, h}$ represents the responses outside both states (e.g. low-debt non-recessionary periods). In the figures, tables and discussion below, we arbitrary label the latter as the "neutral" state of the economy.

\subsection{Business cycle}

Michaillat (2014) shows that the effects of government policies may be stronger in recessionary periods, because there is less crowding out of a rise in public employment on private employment when labor supply is convex. More generally, increases in government purchases might be more effective in recessions since more idle resources should be available for production. The empirical evidence is, however, mixed. Although some studies find the existence of a countercyclical multiplier (Auerbach and Gorodnichenko 2012 and 2013; Baum et al. 2012), Owyang et al. (2013) and Ramey and Zubairy (2014) do not confirm significant higher spending multipliers in recessions. The latter studies use the same local projections method, and a similar sample period as we do. ${ }^{16}$

\footnotetext{
${ }^{15}$ Since we have to estimate the parameters of three states instead of two, we select $L=4$ in order to preserve the number of degrees of freedom.

${ }^{16}$ We also do not find greater multipliers in recessions when we estimate a two-state local projection model. Caggiano et al. (2015) report significant differences only when they consider deep recessions and strong booms.
} 
To check whether our results are not spuriously driven by an overlap of some recessions with the high-debt states, we have estimated the augmented state-dependent local projection model, i.e. equation (3), with $I_{C, t-1}$ as a dummy capturing the NBER recessions. ${ }^{17}$ The possible overlap of the states is shown in panel (a) of Figure 8, while the estimated effects on government spending, GDP, personal consumption and investment are presented in Figure 9. The panels contain the impact in the neutral state of the economy, together with respectively the effects in the high-debt state (controlling for the business cycle), and the effects in a recession (controlling for the state of private debt). The corresponding (cumulative) multipliers are reported in Table 4.

The results confirm that multipliers are much higher in periods of debt overhang, irrespective of the state of the business cycle. We still find crowding-in effects on personal consumption and investment, and output multipliers significantly larger than one. Conversely, government spending multipliers are below one in other periods, including NBER recessions. Thus, by controlling for the presence of private debt overhang, multipliers are not greater in recessions, i.e. the estimated impact in recessions is not significantly different from the neutral state of the economy. ${ }^{18}$

\subsection{Zero lower bound on nominal interest rates}

Recent theoretical research (e.g. Eggertsson and Woodford 2003; Christiano et al. 2011) argues that the multiplier is much larger when the zero lower bound on the nominal interest rate is binding. The mechanism can be described as follows. An increase (decrease) in government spending leads to a rise (fall) in inflation expectations. When the nominal interest rate is held constant, this results in a fall (rise) of the real interest rate, spurring (repressing) the economy. Christiano et al. (2011) show that the multiplier can be much larger than one when the nominal interest rate does not respond to an increase in government purchases. Notice that also the estimated responses of the nominal interest rate in both states turn out to be insignificant (see section 5). However, Carrillo and Poilly

\footnotetext{
${ }^{17}$ We have also done this exercise with the high unemployment states variable of Owyang et al. (2013) and Ramey and Zubairy (2014), where high unemployment states are defined as periods when the unemployment rate was above 6.5 percent. The results are shown in the on-line appendix.

${ }^{18}$ For some horizons, we find significant larger consumption multipliers in recessions relative to the neutral state of the economy, but this result is not robust for the alternative business cycle indicator based on the unemployment rate reported in the on-line appendix. All other conclusions are the same for the unemployment indicator, in particular the finding of a much higher multiplier in high-debt states.
} 
(2013) show that the government spending multiplier rises in a liquidity trap, beyond the impact on the interest rate.

To examine whether the zero lower bound on the interest rate has affected our results, we have also estimated the augmented model by including a dummy variable for the periods when the interest rate was near the zero lower bound or characterized by extended monetary accommodation. To do so, we use the dummy variable of Ramey and Zubairy (2014), who identify two such periods, i.e. 1932Q2-1951Q1 and 2008Q4-2013Q4. As can be seen in Figure 8, there has indeed been an overlap with periods of private debt overhang, in particular in the 1930s.

The results can be found in Figure 10 and Table 4. Notice that the estimates are not always very accurate. We should thus be careful when interpreting the results. ${ }^{19}$ For the defense news shock, the estimated multipliers are much more modest in high-debt states than the benchmark results (see Table 4), but still significantly higher than the neutral state of the economy for at least two years after the shock. The same conclusion applies for the zero lower bound state, i.e. multipliers are below one, but defense news shocks have a stronger effect in these periods relative to the neutral state. The latter result is, however, mainly the consequence of extreme low multipliers in the neutral state, and more importantly, not robust for the TVP-VAR shocks. The estimated multipliers for the TVP-VAR shocks at the zero lower bound are also below one, but not significantly different from the neutral state of the economy. In other words, we cannot draw robust conclusions on the influence of the zero lower bound on spending multipliers. On the other hand, we find a strong crowding-in effect of government spending in high-debt states, and multipliers significantly larger than one in periods of debt overhang for the TVP-VAR shocks. Moreover, the magnitudes are in line with the benchmark results. Overall, we can conclude that spending multipliers are considerably larger when we control for the zero lower bound, but the influence of the zero lower bound itself is uncertain.

\footnotetext{
${ }^{19}$ Notice also the very large numbers and sign switch at the three year horizon of the multiplier in the neutral state, as well as the differences with the other states (see Table 4). The reason for this switch is that cumulative government spending becomes very small and negative beyond the two year horizon (as can be seen in Figure 10). The sign switch of government spending also triggers a sign switch in the cumulative multipliers and the differences. For this reason, the multipliers at the three year horizon do not have a meaningful interpretation. The same applies for the confidence bands of the TVP-VAR shocks beyond the two year horizon.
} 


\subsection{Government debt}

As a final check, we assess whether we still find greater multipliers in high private debt states when we control for government debt overhang. Periods of rising private debt are often accompanied by a decline in government debt, and vice versa, which could also affect the multiplier. ${ }^{20}$ In particular, Perotti (1999) shows that the multiplier is a negative function of the initial government debt level. The higher the debt owned by the government, the higher the expected future tax rate when tax distortions are convex, resulting in a stronger negative wealth effect on private consumption. For a panel of 19 OECD-countries, Perotti (1999) finds evidence that government expenditure shocks have a large positive effect on private consumption when government debt is low, whereas this effect vanishes when debt-to-GDP levels are high. Giavazzi and Pagano (1990) provide international evidence of expansionary fiscal consolidations at exceptionally high debt-toGDP levels. We are not aware of empirical studies that have examined the impact of government debt on spending multipliers in the United States.

To define periods of government debt overhang, we use the same method as described in section 3 for private debt, i.e. periods of government debt overhang are identified as the periods when there was a positive deviation of the government debt-to-GDP ratio from a smooth HP trend. The result of this exercise is shown in panel (c) of Figure 8, the estimated response functions are presented in Figure 11, while the multipliers can be found in Table 4. The results confirm the main findings in this paper: spending multipliers are significantly greater than one and much larger in high-debt states, while there is crowdingout of personal consumption and investment in other periods. The latter is also the case in periods of government debt overhang. Interestingly, we even find more crowding-out effects and significant lower multipliers in periods of high government debt than in the neutral state for the TVP-VAR shocks, i.e. the estimated multipliers are on average 0.25 lower when government debt is above its trend. Also for the defense news shocks, we find more subdued multipliers in high government debt states, but the differences with the neutral state are statistically not significant.

\footnotetext{
${ }^{20}$ For example, this could be a direct consequence of Ricardian behavior of intertemporal optimizing agents.
} 


\section{Conclusions}

In this paper, we have used state-dependent local projection methods and historical U.S. data to examine whether government spending multipliers have been different in periods of private debt overhang. The latter have been identified as periods when the private nonfinancial debt-to-GDP ratio was above its long-term trend. We have compared the effects of respectively narrative defense news shocks and innovations to government purchases obtained from a time-varying VAR model.

We find that government spending multipliers were considerably larger in periods of private debt overhang. Specifically, in periods when the debt-to-GDP ratio was below its trend, the estimated spending multipliers turn out to be significantly below one, which is the consequence of a crowding-out effect of government purchases on personal consumption and investment. These effects are in line with Neoclassical and some New-Keynesian models. The picture, however, totally changes in periods of ample private debt. The estimated multipliers in high-debt states are significantly greater than one, and even reach values above three. This is the result of a strong crowding-in effect on personal consumption and investment activities, a feature which is more in line with traditional Keynesian models. Moreover, we find that the government debt-to-GDP ratio decreases after an expansionary shock to government purchases in high-debt states, while there is a stronger decline of the private debt-to-GDP ratio. Both features could act as an amplifier of fiscal policy measures in periods of private debt overhang.

These results are new stylized facts, and deserve additional research. For example, it is not clear what the exact reason is for the different behavior of the private sector in periods of debt overhang. Can it be explained by borrowing constraints or rule-of-thumb behavior of households, as in the models of Eggertsson and Krugman (2012) and Galí et al. (2007)? Is it driven by a much higher marginal propensity to consume of highly-leveraged households, a feature that has been documented by Mian and Sufi (2014)? Or are there alternative explanations? These are all issues that could be explored in future research. Another relevant extension of our analysis is the question whether also tax multipliers are different across private debt states.

Our findings also have some relevant policy implications. In particular, the state of private debt seems to be an important indicator for the consequences of fiscal consolidations and stimulus programs. In periods of debt overhang and deleveraging in the private 
sector, it is probably not a good idea to conduct austerity policies, because it could have dramatic effects on economic activity. In contrast, deficit-financed government purchases policies could significantly stimulate and stabilize the economy in periods when households are deleveraging and depressing aggregate demand. On the other hand, once private debt levels are again below trend, the timing is perfect to conduct fiscal consolidations, having little consequences for economic activity. 


\section{A Data}

Below we list the data used in the empirical analysis. For each variable, we report the sample period, the formula together with the official mnemonics, the aggregation method and the source.

\begin{tabular}{|c|c|c|c|c|}
\hline Var. & Sample & Formula \& official abbreviations & Aggr. & Source \\
\hline \multirow[t]{2}{*}{ GOV } & 1919Q1-1946Q4 & G & GR & GK10 \\
\hline & 1947Q1-2013Q4 & GCE/GDPCTPI & & FRED \\
\hline \multirow[t]{2}{*}{ GDP } & 1919Q1-1946Q4 & Y & GR & GK10 \\
\hline & 1947Q1-2013Q4 & GDP/GDPCTPI & & FRED \\
\hline \multirow[t]{2}{*}{$\mathrm{CON}$} & 1919Q1-1946Q4 & $\mathrm{CND}+\mathrm{CS}$ & GR & GK10 \\
\hline & 1947Q1-2013Q4 & $(\mathrm{PCND}+\mathrm{PCESV}) / \mathrm{GDPCTPI}$ & & FRED \\
\hline \multirow[t]{2}{*}{ INV } & 1919Q1-1946Q4 & IPDE+IRES+INRES & GR & GK10 \\
\hline & 1947Q1-2013Q4 & FPI/GDPCTPI & & FRED \\
\hline \multirow[t]{2}{*}{ POP } & 1919Q1-1951Q4 & pop & GR & ORZ13 \\
\hline & 1952Q1-2013Q4 & POP & & FRED \\
\hline \multirow[t]{2}{*}{ PRY } & 1919Q1-1951Q4 & $(C j 875-C j 887) / C a 10$ & GR & HSUS \\
\hline & 1952Q1-2013Q4 & (TODNS-SLGSDODNS-FGSDODNS)/GDP & & FRED \\
\hline \multirow[t]{2}{*}{ GVY } & 1919Q1-1951Q4 & Cj871/Ca10 & GR & HSUS \\
\hline & 1952Q1-2013Q4 & (SLGSDODNS+FGSDODNS)/GDP & & FRED \\
\hline REC & 1919Q1-2013Q4 & USRECQ & & FRED \\
\hline \multirow[t]{2}{*}{ UNE } & 1919Q1-1947Q4 & unemp & ST & ORZ13 \\
\hline & 1948Q1-2013Q4 & UNRATE & & FRED \\
\hline \multirow[t]{3}{*}{ NIR } & 1919Q1-1946Q4 & $\mathrm{R}$ & ST & GK10 \\
\hline & 1947Q1-1955Q4 & M13009USM156NNBR & ST & FRED \\
\hline & 1956Q1-2013Q4 & $\mathrm{FF}$ & & FRED \\
\hline \multirow[t]{2}{*}{ TAX } & 1919Q1-1949Q4 & Federal individual income tax & ST & BR11 \\
\hline & 1950Q1-2013Q4 & All tax units (series 1) & & M13 \\
\hline
\end{tabular}

The analyzed variables are: real government purchases (GOV), real gross domestic product (GDP), real consumption $(\mathrm{CON})$, real investment (INV), population (POP), private nonfinancial debt-to-GDP ratio (PRY), government debt-to-GDP ratio (GVY), 
NBER recessions (REC), unemployment rate (UNE), nominal interest rate (NIR) and average marginal tax rate (TAX). Data related to different sources are aggregate either using the growth rate (GR) or simply by stacking (ST). The sources are Federal Reserve Economic Data (FRED), Gordon and Krenn 2010 (GK10), Barro and Redlick 2011 (BR11), Mertens 2013 (M13), Owyang et al. 2013 (ORZ13) and Carter et al. 2006 (HSUS). The formulas in italics indicate that the original data are available in annual frequency ${ }^{21}$.

\section{B Error bands for cumulative spending multipliers}

Here we briefly explain step by step how we have constructed the error bands of the cumulative spending multipliers reported in Tables 1-3.

1. Estimation of the Local Projections (LPs)

Estimate the LPs related to government purchases $(G)$ and GDP $(Y)$, i.e. for each dependent variable $k=\{G, Y\}$ and for each horizon $h=[0, H]$, store the estimated vector of parameters $\beta_{h}^{k}$ and its Newey-West variance-covariance matrix $V_{h}^{k}$.

2. Construction of the aggregate beta mean

The aggregate beta mean is given by the following expression:

$$
\beta_{M}=\left[\beta_{0}^{Y}, \beta_{0}^{G}, \cdots, \beta_{H}^{Y}, \beta_{H}^{G}\right]
$$

3. Construction of the aggregate beta variance-covariance

The aggregate beta variance-covariance is given by the following expression:

$$
\beta_{V}=\operatorname{diag}\left(\left[V_{0}^{Y}, V_{0}^{G}, \cdots, V_{H}^{Y}, V_{H}^{G}\right]\right)
$$

where diag indicates the diagonal operator.

4. Generation of the draws from the aggregate multivariate normal distrubution

Draw 1000 times from the following distribution,

$$
\beta \sim \mathcal{N}\left[\operatorname{vec}\left(\beta_{M}\right), \beta_{V}\right]
$$

where vec indicates the vector operator. For each draw, calculate the state dependent fiscal multipliers and their difference.

\footnotetext{
${ }^{21}$ Concerning the debt-to-GDP ratios, we transform the series in quarterly frequency using the cubic spline interpolation. Concerning the tax rate, annual figures are repeated for each quarter in the year.
} 
5. Construction of the error bands

For each object of interest (e.g. the state dependent cumulative spending multipliers and their difference), sort the draws and select the percentiles $\left\{\frac{\alpha}{2}, \frac{1-\alpha}{2}\right\}$, where $\alpha$ is the selected significance level. 


\section{References}

[1] Auerbach, Alan. J. and Yuriy Gorodnichenko, 2012. "Measuring the Output Responses to Fiscal Policy," American Economic Journal: Economic Policy, American Economic Association, vol. 4(2), pages 1-27, May.

[2] Auerbach, Alan. J. and Yuriy Gorodnichenko, 2013. "Fiscal Multipliers in Recession and Expansion," NBER Chapters, in: Fiscal Policy after the Financial Crisis, pages 63-98 National Bureau of Economic Research, Inc.

[3] Barro, Robert J. and Charles J. Redlick, 2011. "Macroeconomic Effects From Government Purchases and Taxes," The Quarterly Journal of Economics, Oxford University Press, vol. 126(1), pages 51-102.

[4] Baum, Anja, Marcos Poplawski-Ribeiro and Anke Weber, 2012. "Fiscal Multipliers and the State of the Economy," IMF Working Papers 12/286, International Monetary Fund.

[5] Baxter, Marianne and King, Robert G, 1993. "Fiscal Policy in General Equilibrium," American Economic Review, American Economic Association, vol. 83(3), pages 31534, June.

[6] Bernanke, Ben S., 1983. "Nonmonetary Effects of the Financial Crisis in Propagation of the Great Depression," American Economic Review, American Economic Association, vol. 73(3), pages 257-76, June.

[7] Bernanke, Ben S. and Gertler, Mark, 1989. "Agency Costs, Net Worth, and Business Fluctuations," American Economic Review, American Economic Association, vol. 79(1), pages 14-31, March.

[8] Bernardini, Marco and Gert Peersman, 2015. "The Time-Varying Government Spending Multiplier: Evidence Based on a Century of U.S. Quarterly Data," Mimeo, Ghent University.

[9] Blanchard, Olivier J. and Daniel Leigh, 2013. "Growth Forecast Errors and Fiscal Multipliers," American Economic Review, American Economic Association, vol. 103(3), pages 117-20, May. 
[10] Blanchard, Olivier J and Roberto Perotti, 2002. "An Empirical Characterization Of The Dynamic Effects Of Changes In Government Spending And Taxes On Output," The Quarterly Journal of Economics, MIT Press, vol. 117(4), pages 1329-1368, November.

[11] Caggiano, Giovanni, Efrem Castelnuovo, Valentina Colombo and Gabriela Nodari, 2015. "Estimating Fiscal Multipliers: Evidence From a Nonlinear World," Economic Journal, Royal Economic Society, forthcoming.

[12] Carter, Susan B., Scott Sigmund Gartner, Michael R. Haines, Alan L. Olmstead, Richard Sutch, Gavin Wright, and Richard Sutch, 2006. "Table Ca9-19: Gross domestic product: 1790-2002 [Continuous annual series]," "Table Cj870-889: Net public and private debt, by major sector: 1916-1976." In Historical Statistics of the United States Millennial Edition Online. Cambridge University Press.

[13] Carrillo, Julio and Celine Poilly, 2013. "How Do Financial Frictions Affect the Spending Multiplier During a Liquidity Trap?," Review of Economic Dynamics, Elsevier for the Society for Economic Dynamics, vol. 16(2), pages 296-311, April.

[14] Christiano, Lawrence, Martin Eichenbaum and Sergio Rebelo, 2011. "When Is the Government Spending Multiplier Large?," Journal of Political Economy, University of Chicago Press, vol. 119(1), pages 78 - 121.

[15] Eggertsson, Gauti B., 2011. "What Fiscal Policy is Effective at Zero Interest Rates?," NBER Chapters, in: NBER Macroeconomics Annual 2010, Volume 25, pages 59-112 National Bureau of Economic Research, Inc.

[16] Eggertsson, Gauti B. and Paul Krugman, 2012. "Debt, Deleveraging, and the Liquidity Trap: A Fisher-Minsky-Koo Approach," The Quarterly Journal of Economics, Oxford University Press, vol. 127(3), pages 1469-1513.

[17] Eggertsson, Gauti B. and Michael Woodford, 2003. "The Zero Bound on Interest Rates and Optimal Monetary Policy," Brookings Papers on Economic Activity, Economic Studies Program, The Brookings Institution, vol. 34(1), pages 139-235.

[18] Fisher, Irving, 1933. "The Debt-Deflation Theory of Great Depressions," Econometrica, Econometric Society, vol. 4(1), pages 337-357, 01. 
[19] Galí, Jordi and J. David López-Salido \& Javier Vallés, 2007. "Understanding the Effects of Government Spending on Consumption," Journal of the European Economic Association, MIT Press, vol. 5(1), pages 227-270, 03.

[20] Giavazzi, Francesco and Marco Pagano, 1990. "Can Severe Fiscal Contractions Be Expansionary? Tales of Two Small European Countries," NBER Chapters, in: NBER Macroeconomics Annual 1990, Volume 5, pages 75-122 National Bureau of Economic Research, Inc.

[21] Goodhart, Charles and Boris Hofmann, 2008. "House Prices, Money, Credit, and the Macroeconomy," Oxford Review of Economic Policy, Oxford University Press, vol. 24(1), pages 180-205, spring.

[22] Gordon, Robert J. and Robert Krenn, 2010. "The End of the Great Depression 193941: Policy Contributions and Fiscal Multipliers," NBER Working Papers 16380, National Bureau of Economic Research, Inc.

[23] Hall, Robert E., 2009. "By How Much Does GDP Rise If the Government Buys More Output?," Brookings Papers on Economic Activity, Economic Studies Program, The Brookings Institution, vol. 40(2 (Fall)), pages 183-249.

[24] Hall, Robert E., 2011. "The Long Slump," American Economic Review, American Economic Association, vol. 101(2), pages 431-69, April.

[25] Jordà, Òscar, 2005. "Estimation and Inference of Impulse Responses by Local Projections," American Economic Review, American Economic Association, vol. 95(1), pages 161-182, March.

[26] Jordà, Òscar, Moritz Schularick and Alan M. Taylor, 2013. "When Credit Bites Back," Journal of Money, Credit and Banking, Blackwell Publishing, vol. 45(s2), pages 3-28, December.

[27] Krugman, Paul, 2013. End This Depression Now!, W. W. Norton \& Company.

[28] Mertens, Karel, 2013. "Marginal Tax Rates and Income: New Time Series Evidence," NBER Working Papers 19171, National Bureau of Economic Research, Inc.

[29] Mertens, Karel and Morten O. Ravn, 2010. "Measuring the Impact of Fiscal Policy in the Face of Anticipation: A Structural VAR Approach," Economic Journal, Royal Economic Society, vol. 120(544), pages 393-413, 05. 
[30] Mian, Atif and Amir Sufi, 2011. "House Prices, Home Equity-Based Borrowing, and the US Household Leverage Crisis," American Economic Review, American Economic Association, vol. 101(5), pages 2132-56, August.

[31] Mian, Atif and Amir Sufi, 2014. House of Debt: How They (and You) Caused the Great Recession, and How We Can Prevent It from Happening Again, University Of Chicago Press.

[32] Michaillat, Pascal, 2014. "A Theory of Countercyclical Government Multiplier," American Economic Journal: Macroeconomics, American Economic Association, vol. 6(1), pages 190-217, January.

[33] Mishkin, Frederic S., 1978. "The Household Balance Sheet and the Great Depression," The Journal of Economic History, Cambridge University Press, vol. 38(04), pages 918-937, December.

[34] Owyang, Michael T., Valerie A. Ramey and Sarah Zubairy, 2013. "Are Government Spending Multipliers Greater during Periods of Slack? Evidence from TwentiethCentury Historical Data," American Economic Review, American Economic Association, vol. 103(3), pages 129-34, May.

[35] Perotti, Roberto, 1999. "Fiscal Policy In Good Times And Bad," The Quarterly Journal of Economics, MIT Press, vol. 114(4), pages 1399-1436, November.

[36] Perotti, Roberto, 2008. "In Search of the Transmission Mechanism of Fiscal Policy," NBER Chapters, in: NBER Macroeconomics Annual 200\%, Volume 22, pages 169-226 National Bureau of Economic Research, Inc.

[37] Perotti, Roberto, 2013. "Comment on "Government Spending and Private Activity"," NBER Chapters, in: Fiscal Policy after the Financial Crisis, pages 56-61 National Bureau of Economic Research, Inc.

[38] Perotti, Roberto, 2014. "Defense Government Spending Is Contractionary, Civilian Government Spending Is Expansionary," NBER Working Papers 20179, National Bureau of Economic Research, Inc.

[39] Ramey, Valerie A., 2011a. "Identifying Government Spending Shocks: It's all in the Timing," The Quarterly Journal of Economics, Oxford University Press, vol. 126(1), pages $1-50$. 
[40] Ramey, Valerie A., 2011b. "Can Government Purchases Stimulate the Economy?," Journal of Economic Literature, American Economic Association, vol. 49(3), pages 673-85, September.

[41] Ramey, Valerie A. and Sarah Zubairy, 2014. "Government Spending Multipliers in Good Times and in Bad: Evidence from U.S. Historical Data," NBER Working Papers 20719, National Bureau of Economic Research, Inc.

[42] Schularick, Moritz and Alan M. Taylor, 2012. "Credit Booms Gone Bust: Monetary Policy, Leverage Cycles, and Financial Crises, 1870-2008," American Economic Review, American Economic Association, vol. 102(2), pages 1029-61, April. 
Figures and Tables 
Figure 1. Identifying periods of private debt overhang

(a) Private nonfinancial debt-to-GDP ratio

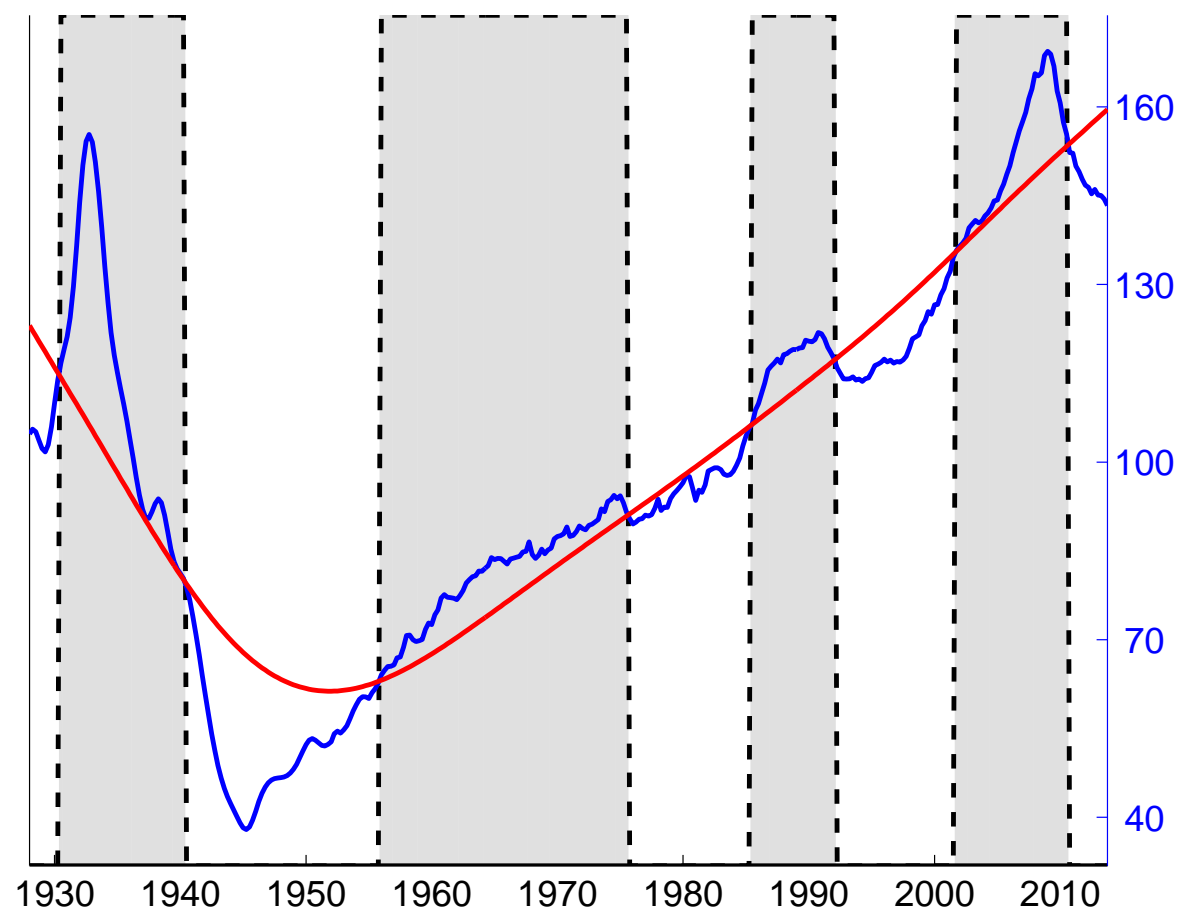

(b) $\mathrm{HP}=1 e 7$

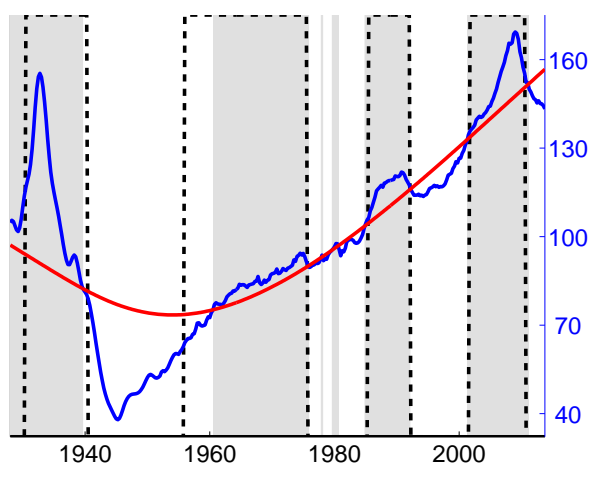

(d) Household debt-to-GDP ratio

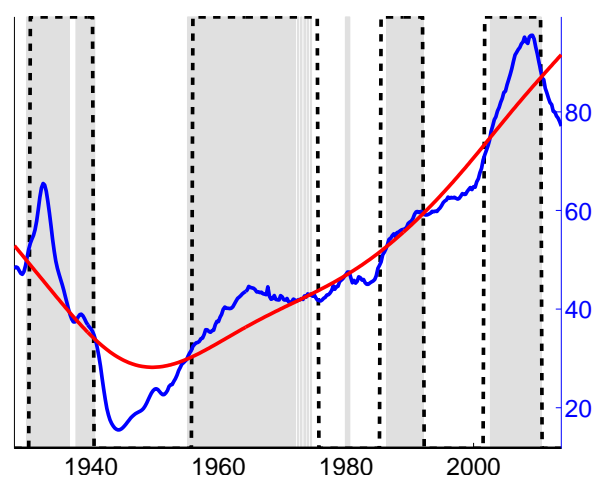

(c) Private debt-to-GDP ratio

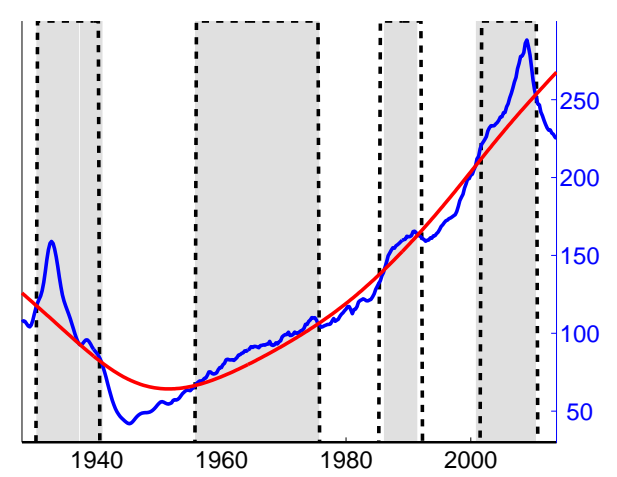

(e) Private nonfinancial real per capita debt level

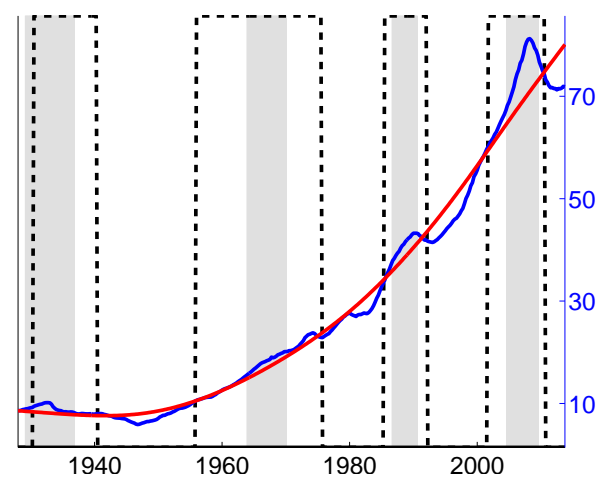

Note: The figure shows the state dummy, together with the original time series and the smooth HP trend. Panel (a) reports the benchmark state dummy, while panels (b-e) report possible alternative state dummies. The dotted lines are the periods of the benchmark state variable. 
Figure 2. Government spending shocks

(a) Defense news

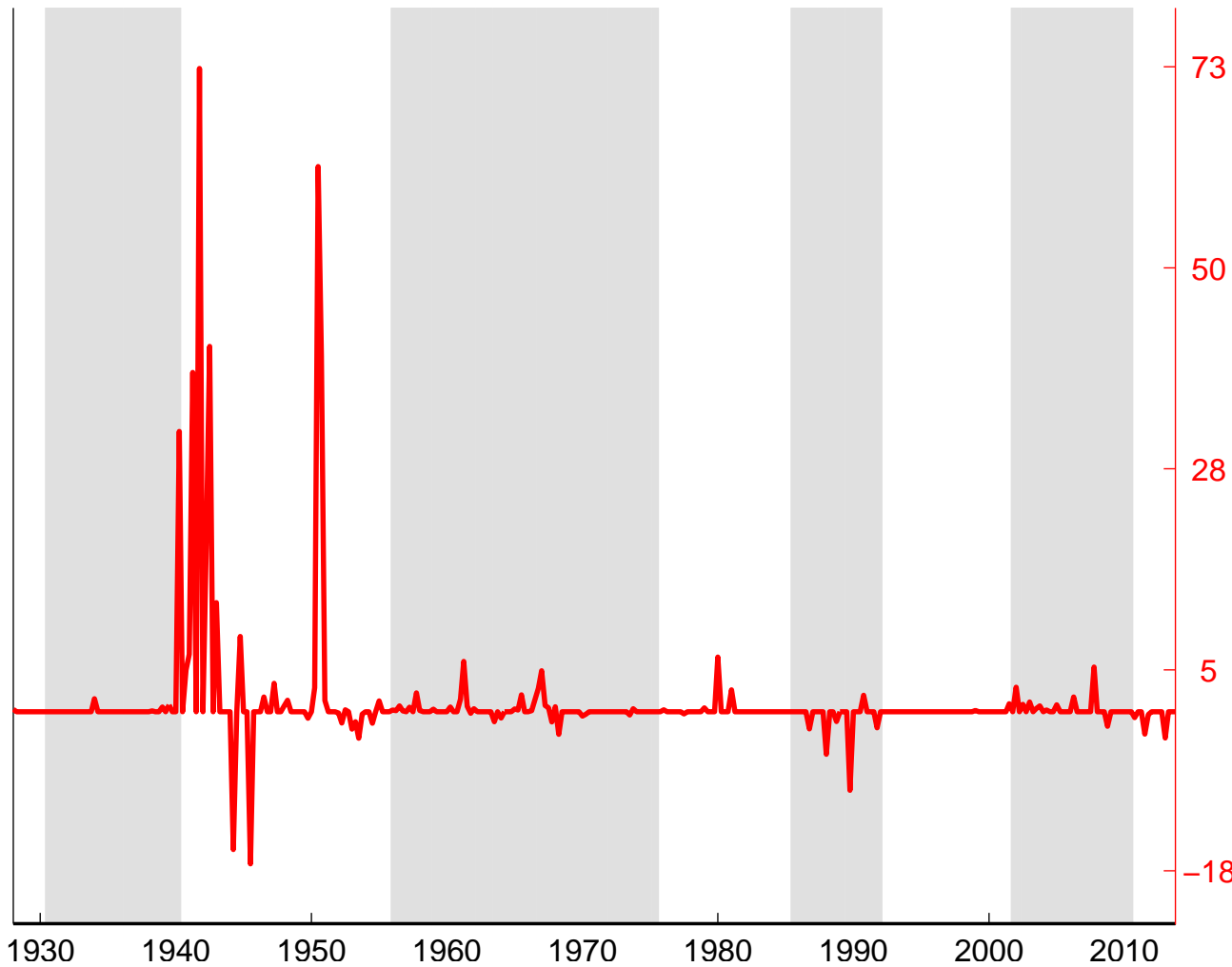

(b) TVP-VAR

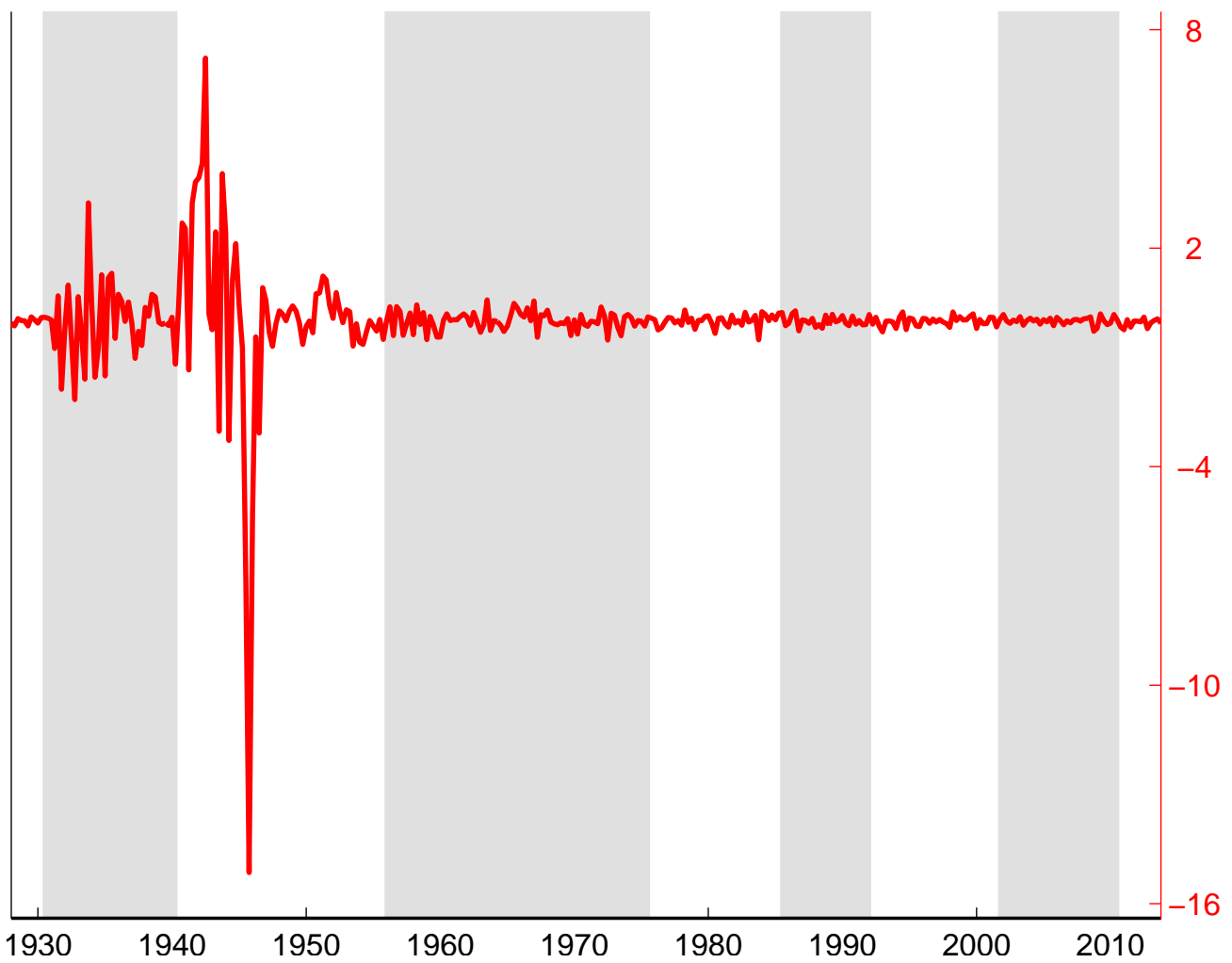

Note: The figure shows the government spending shocks together with the state dummy. Panel (a) shows the defense news shocks, while panel (b) the structural shock derived from a recursively identified TVP-VAR. Both shocks are scaled by lagged GDP and are shown in percentage points. 
Figure 3. Effects of government spending shocks: the linear case

\section{Defense news shocks}

Government spending

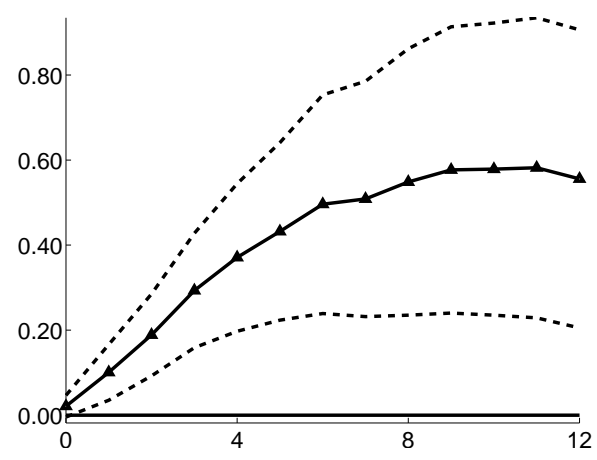

Consumption

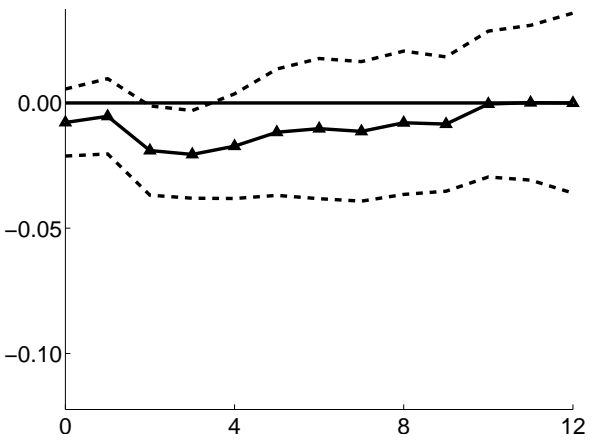

Gross Domestic Product
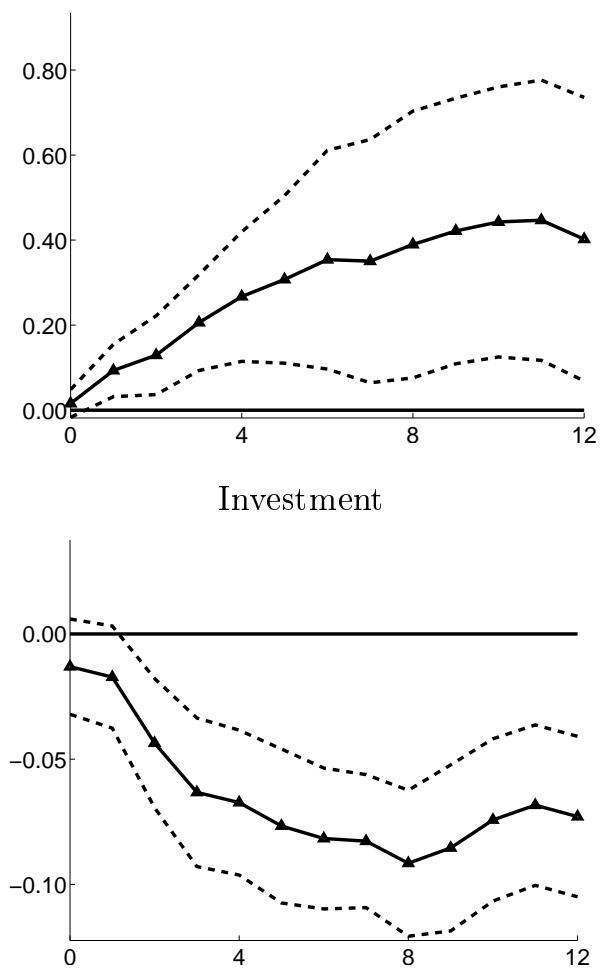

TVP-VAR shocks

Government spending

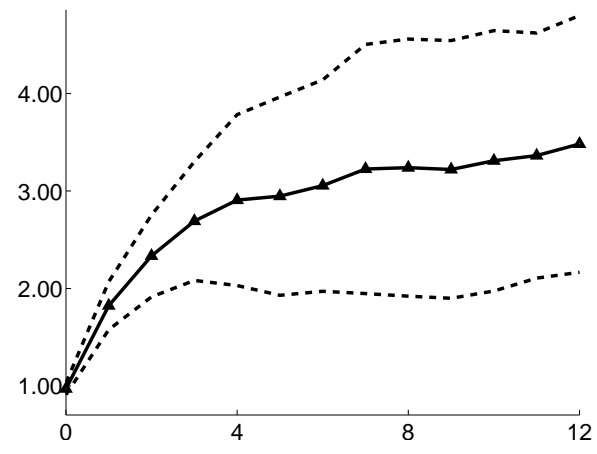

Consumption

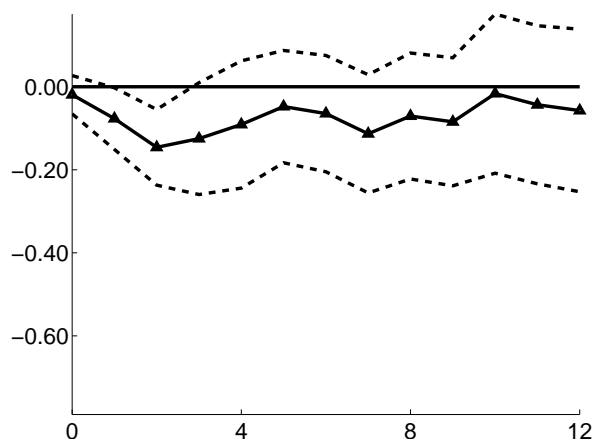

Gross Domestic Product

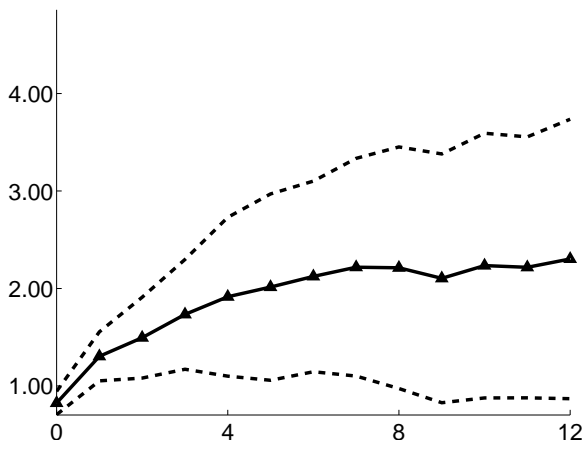

Investment

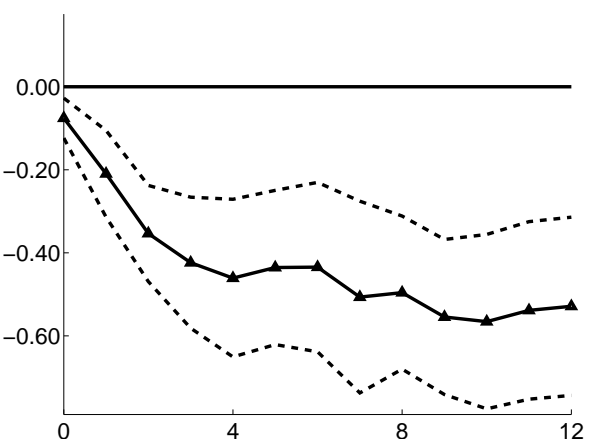


Figure 4. Effects of defense news shocks in high-debt versus low-debt states

Government spending

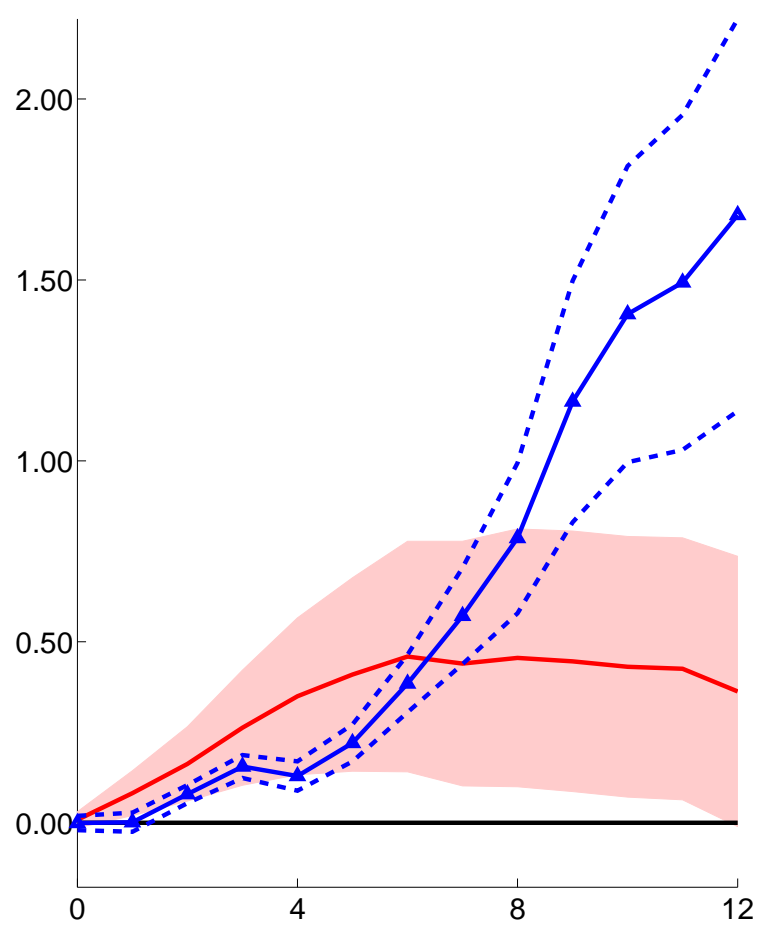

Consumption

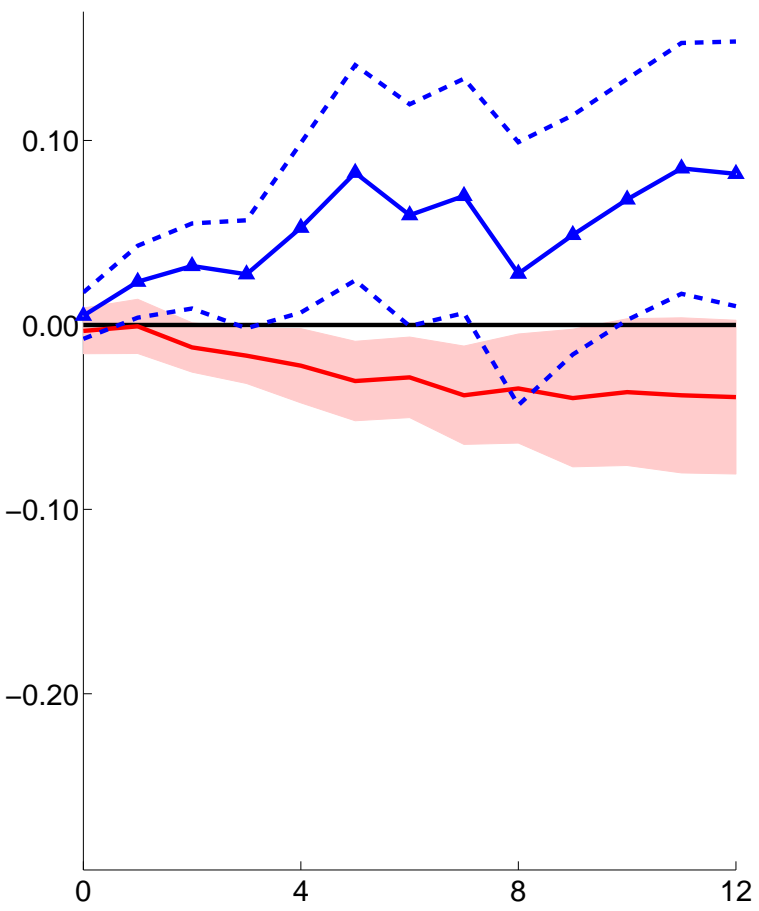

Gross Domestic Product

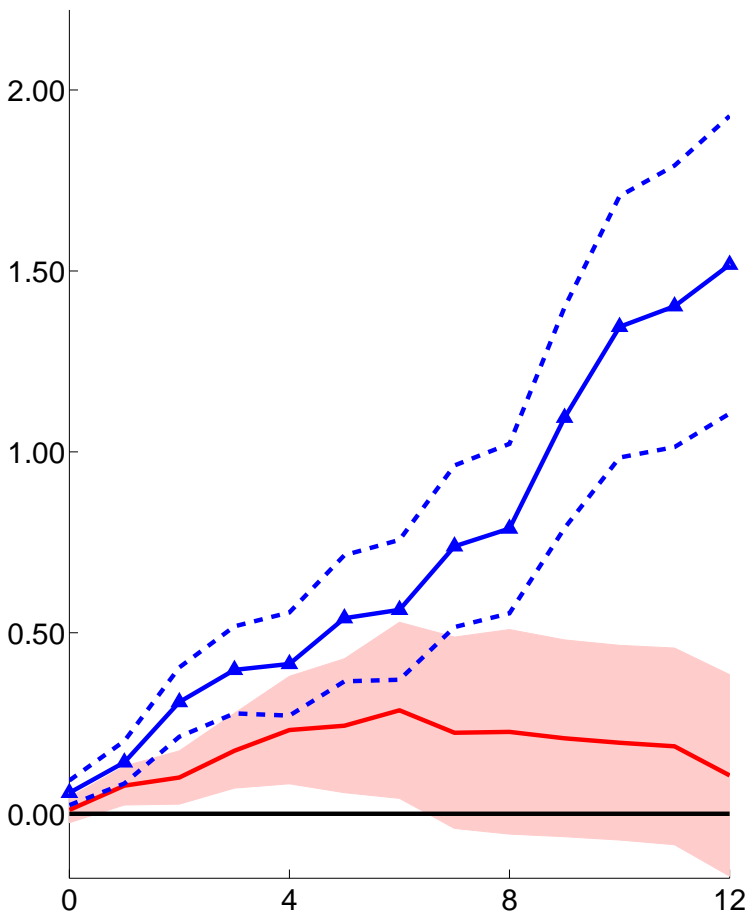

Investment

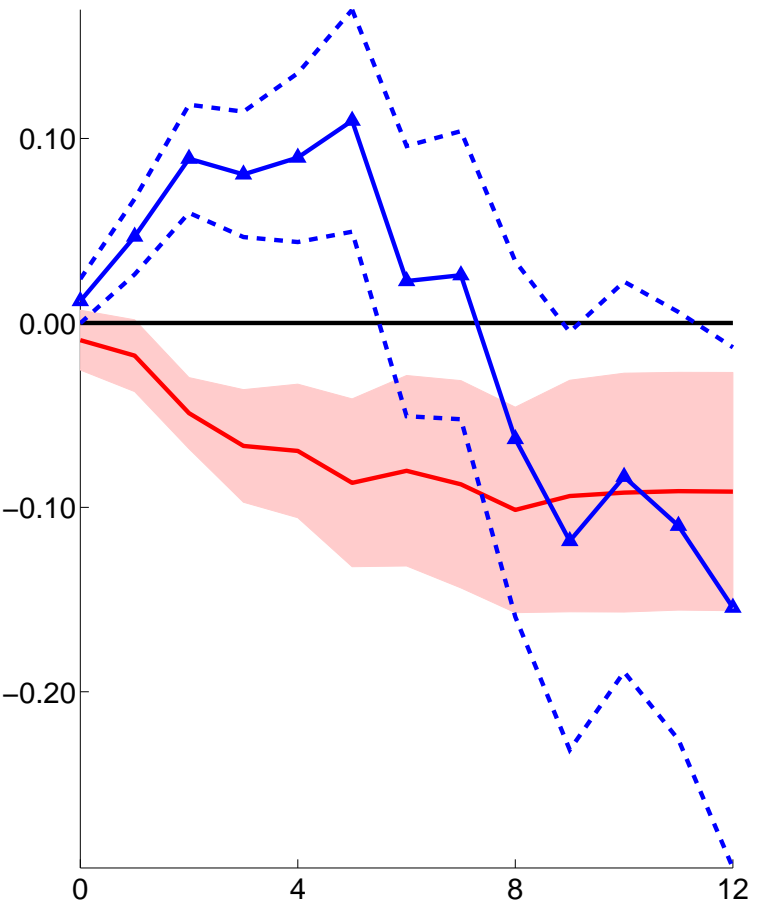

- High private debt (90\% confidence interval) Low private debt ( $90 \%$ confidence interval) 
Figure 5. Effects of TVP-VAR shocks in high-debt versus low-debt states

Government spending

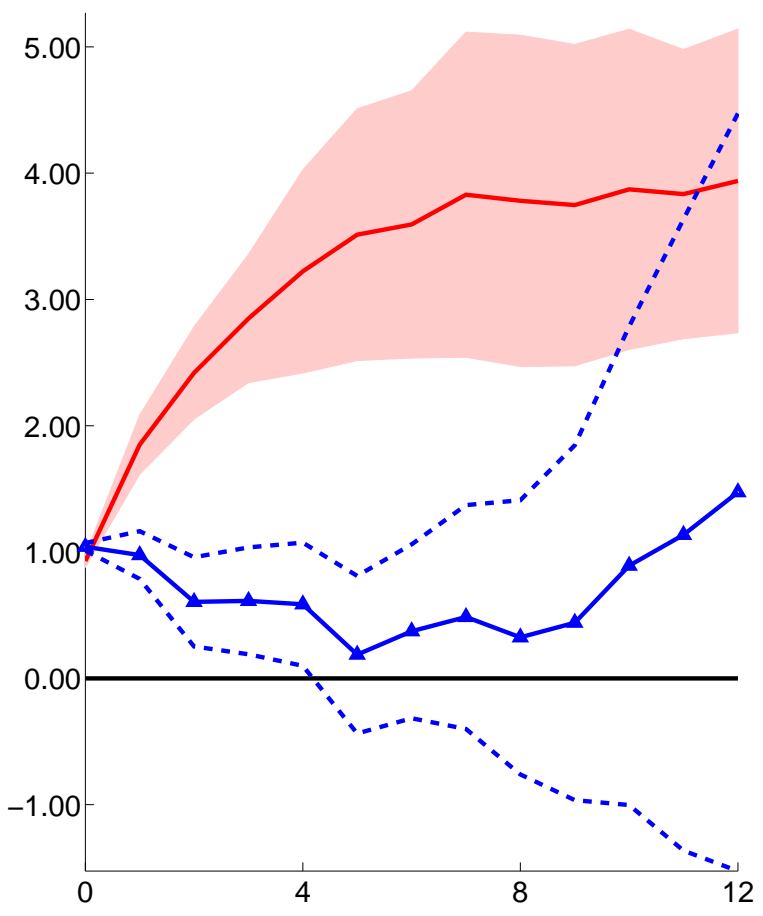

Consumption

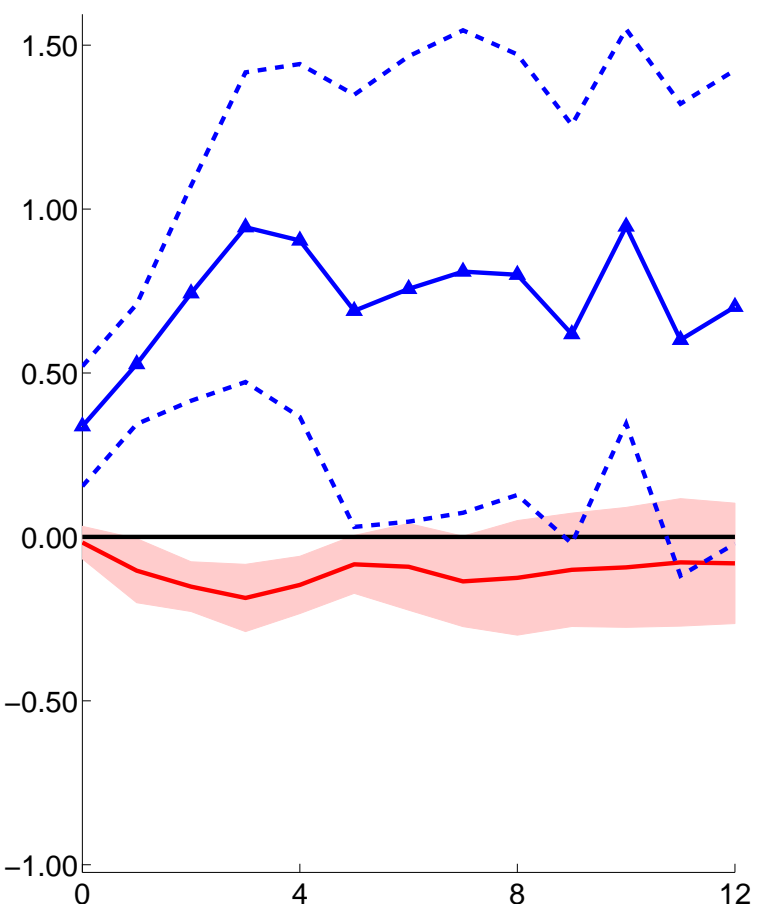

Gross Domestic Product

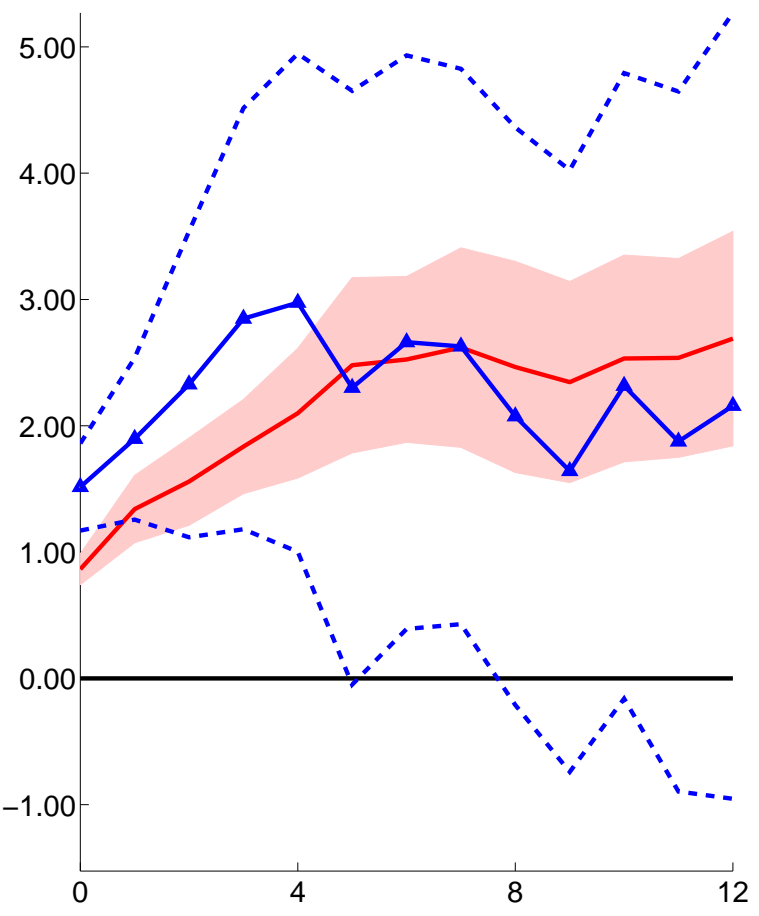

Investment

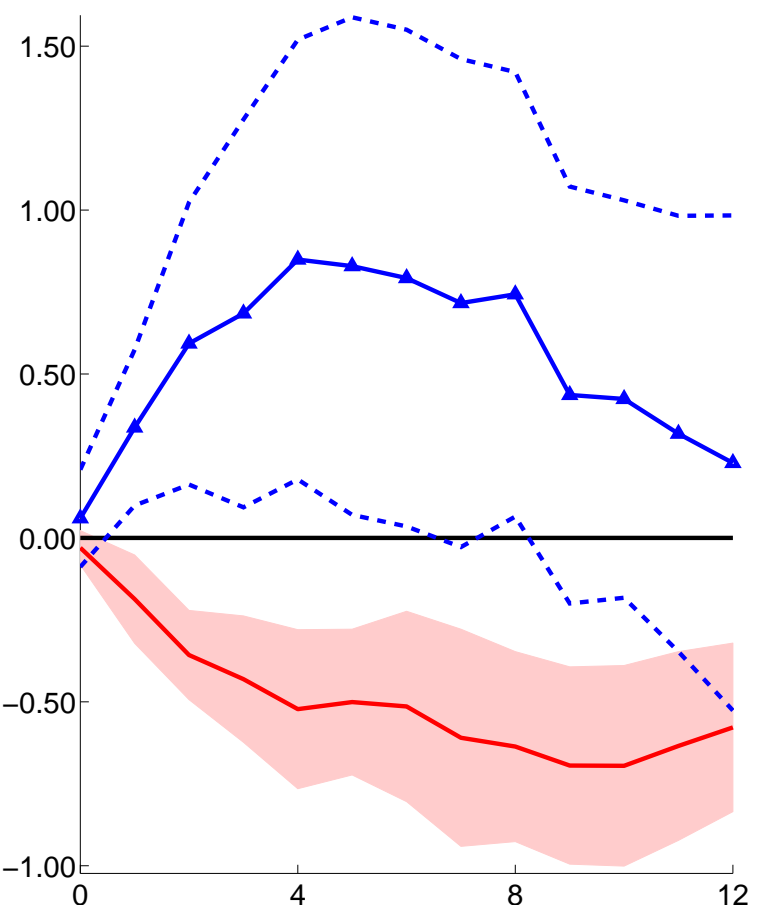


Figure 6. Post WWII estimation results (1947Q1-2013Q4)

\section{Defense news shocks}

Government spending

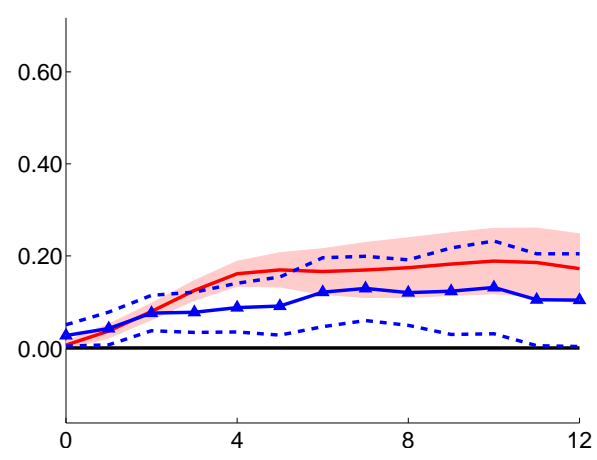

Consumption

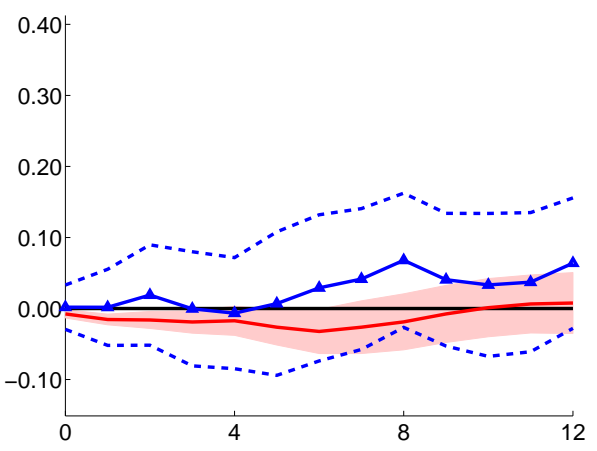

Gross Domestic Product
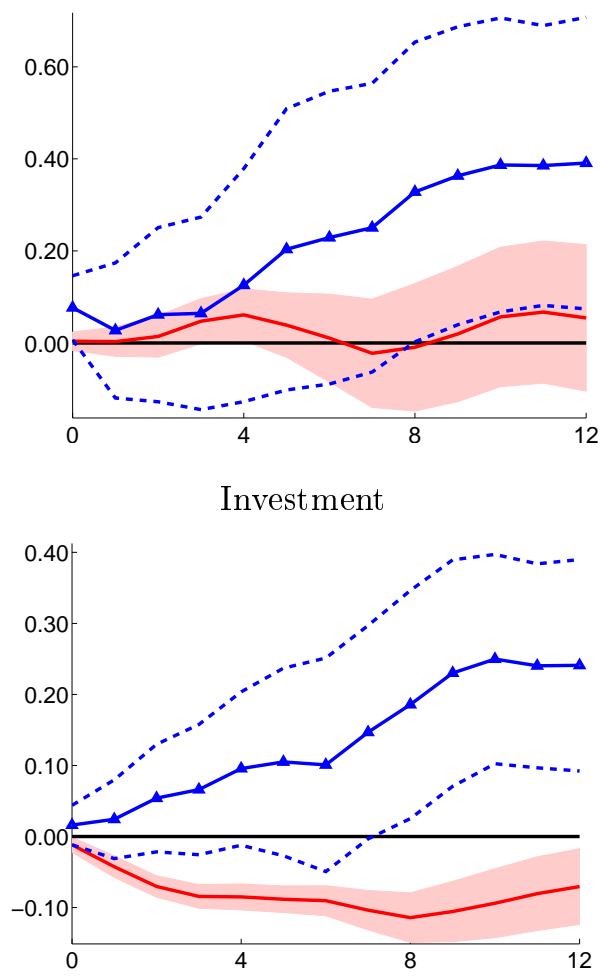

TVP-VAR shocks

Government spending

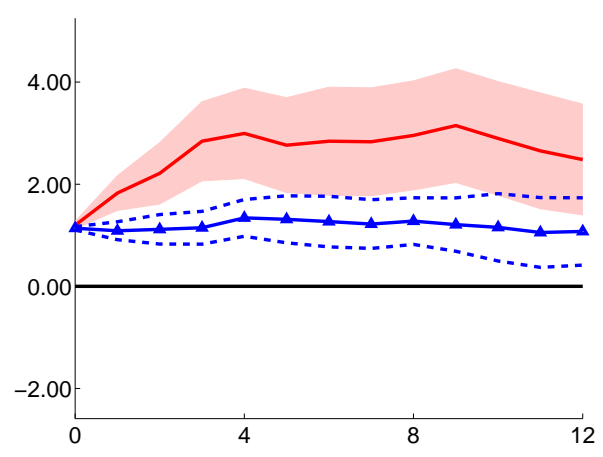

Consumption

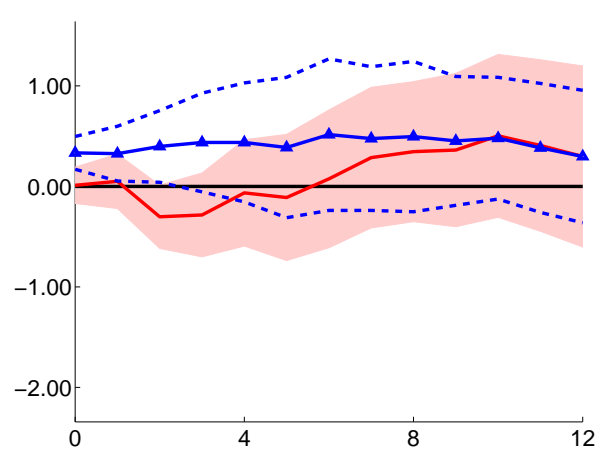

Gross Domestic Product

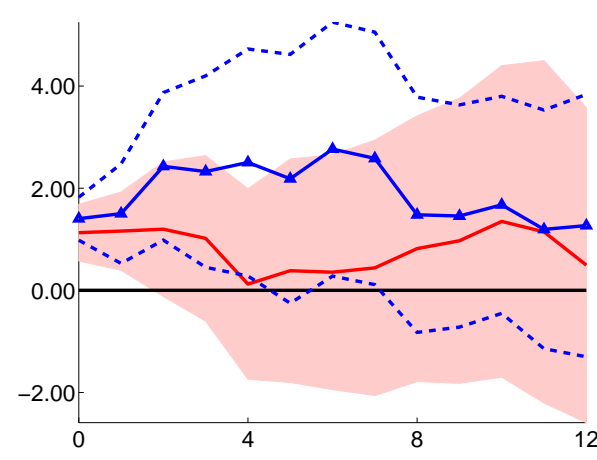

Investment

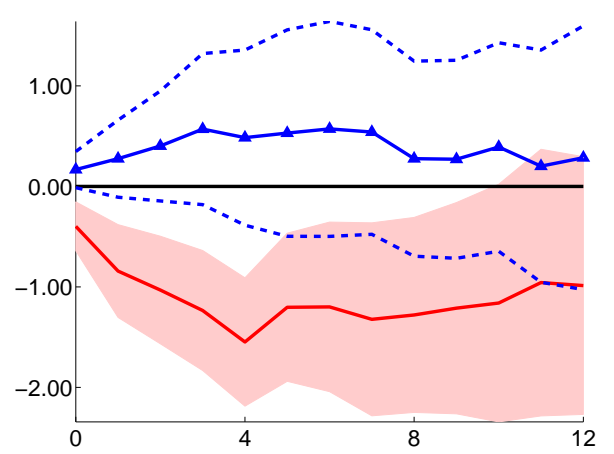


Figure 7. Effects on interest rate, tax rate and debt ratios

\section{Defense news shocks}

Nominal interest rate

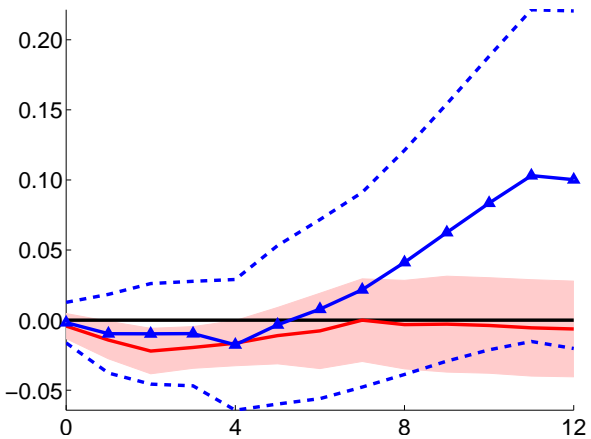

Private debt-to-GDP ratio

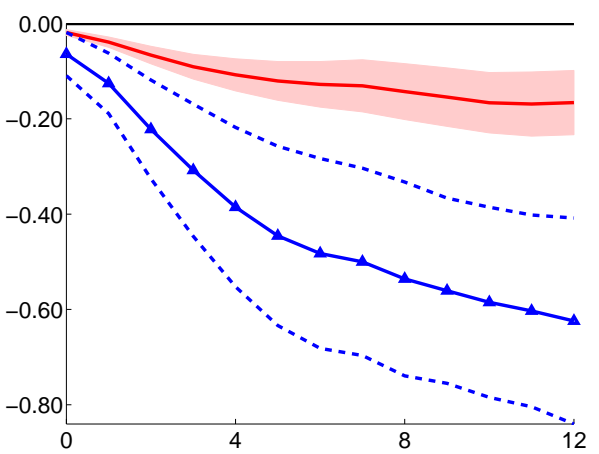

Tax rate

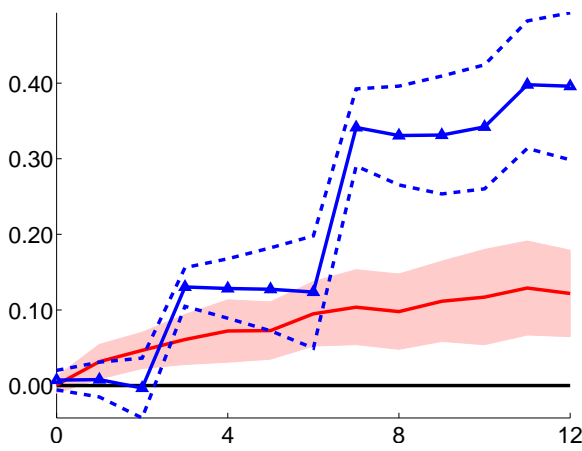

Government debt-to-GDP ratio

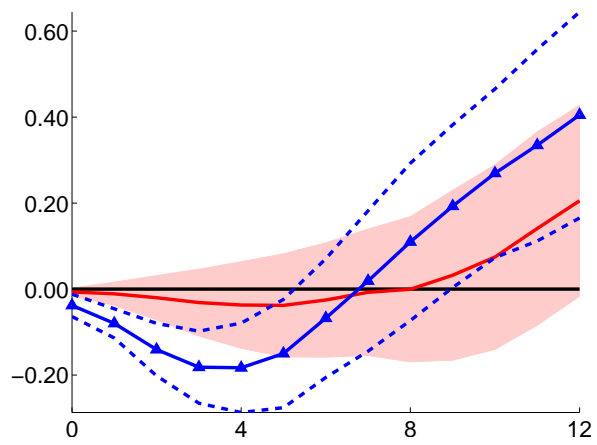

TVP-VAR shocks

Nominal interest rate

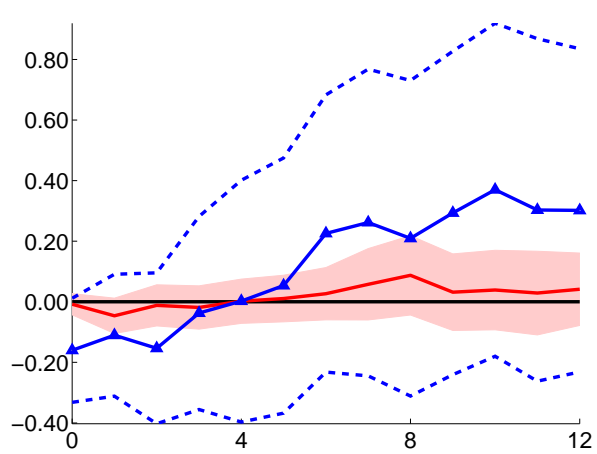

Private debt-to-GDP ratio

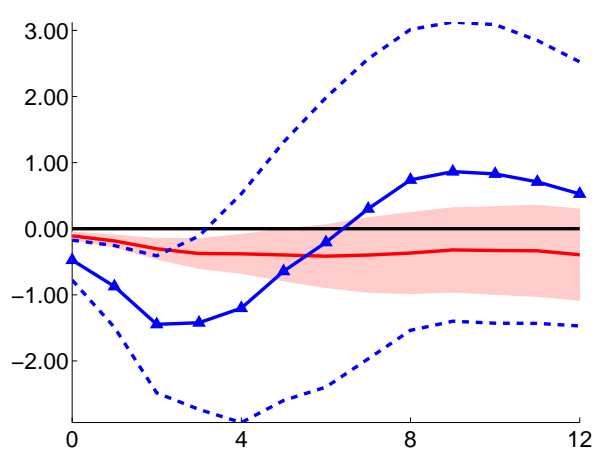

Tax rate

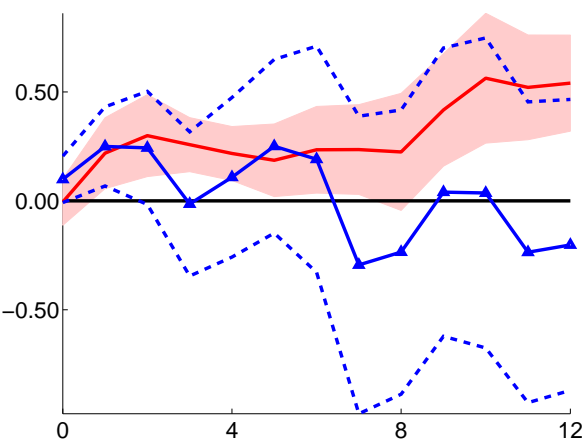

Government debt-to-GDP ratio

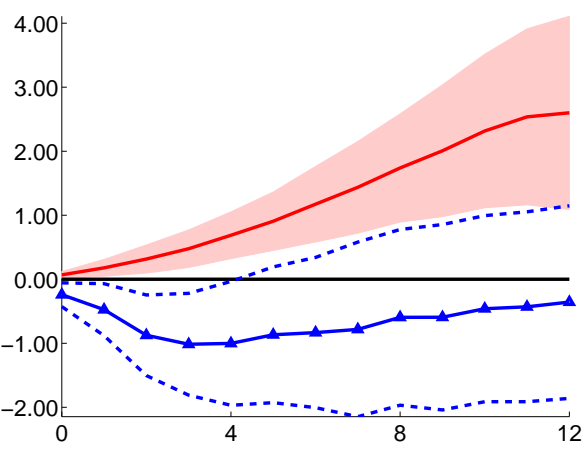


Figure 8. Additional state variables

(a) NBER recessions

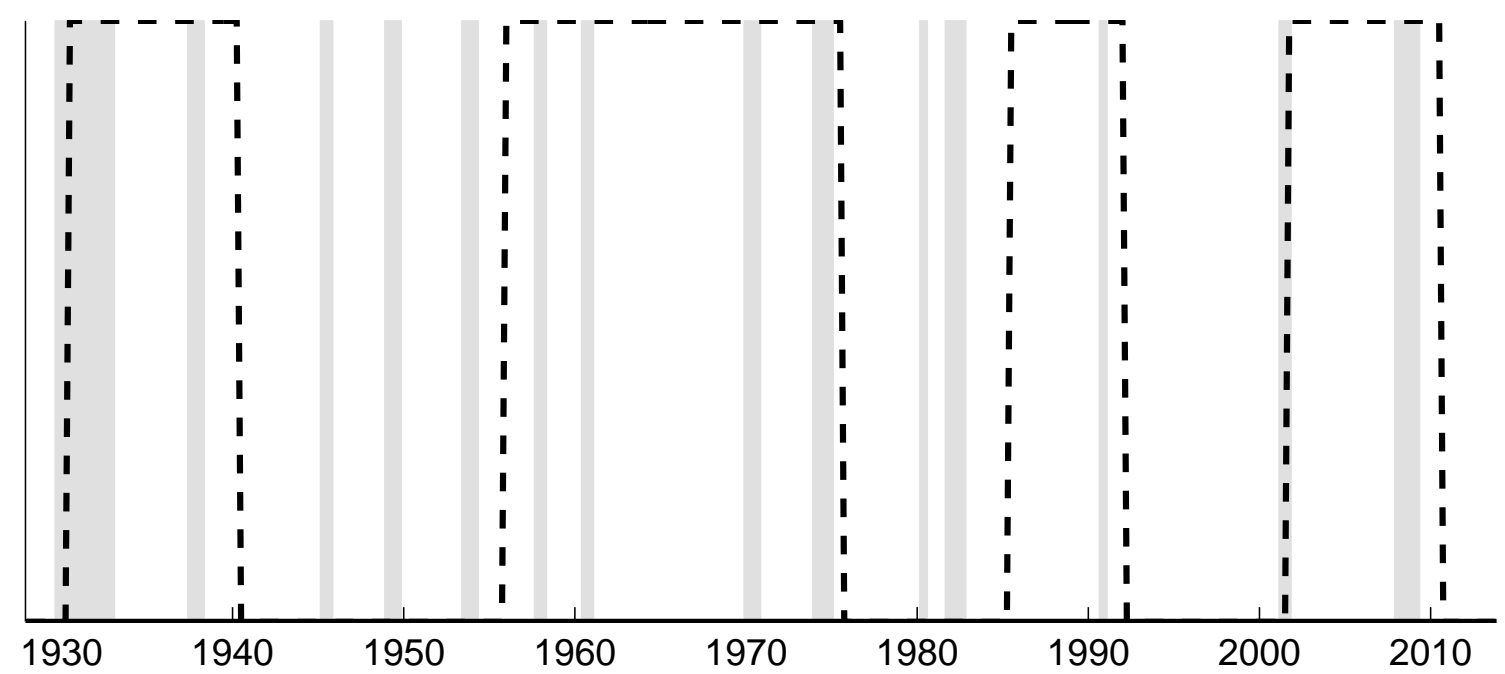

(b) Zero Lower Bound

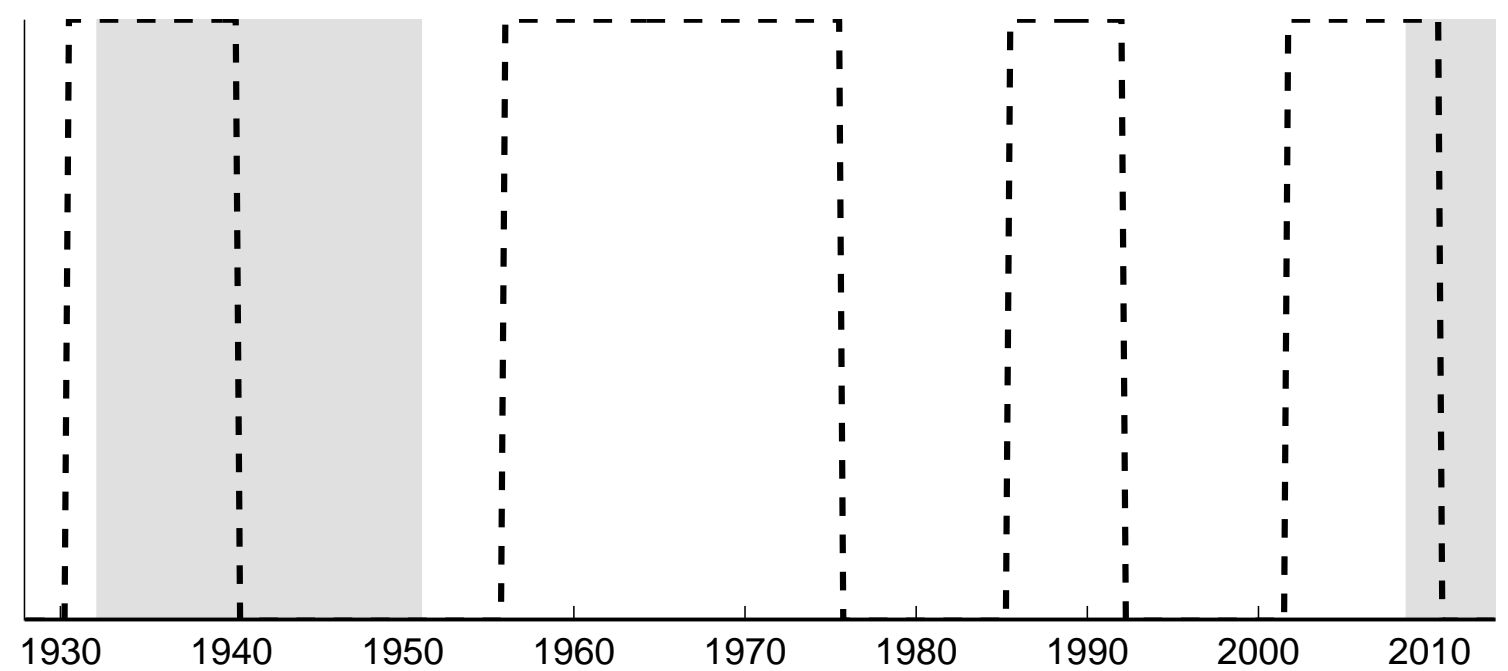

(c) Government debt overhang

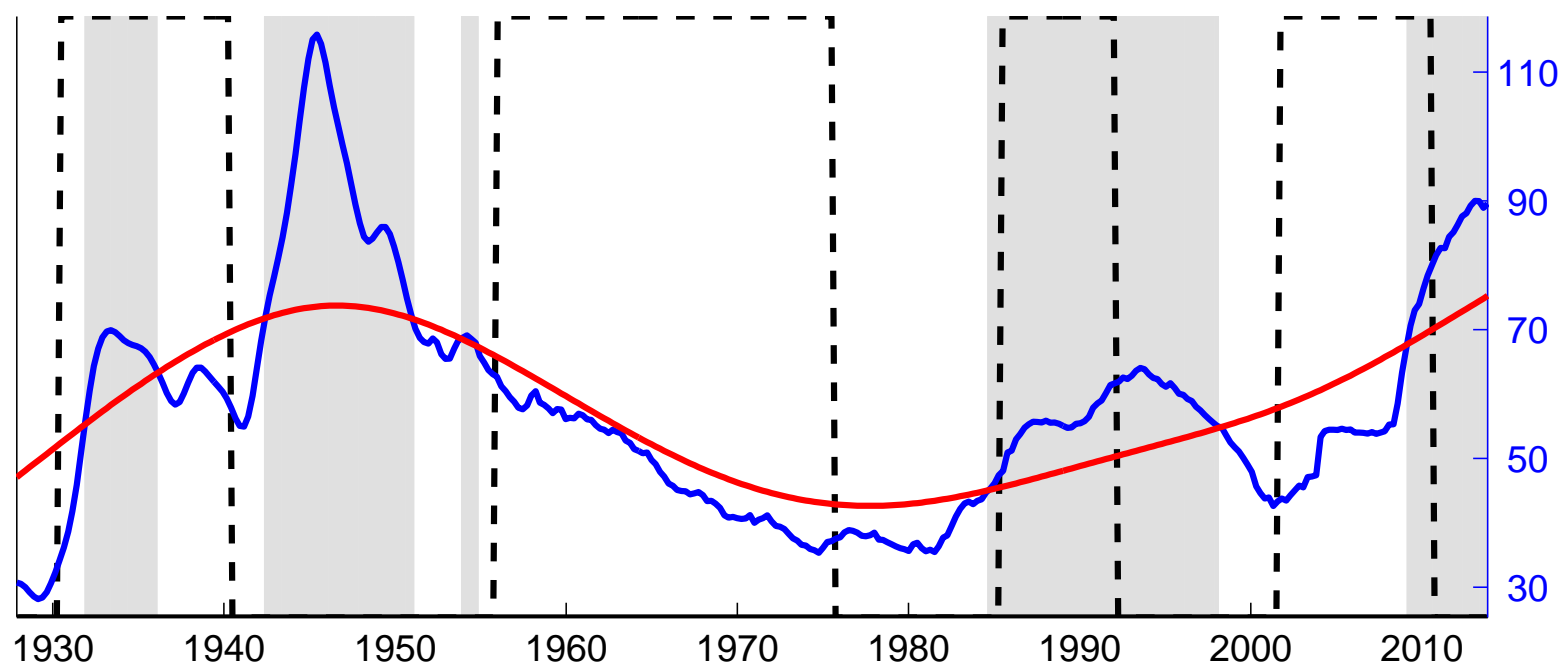

Note: The figure shows the additional state dummies analyzed in the augmented model. The dotted lines are periods of private debt overhang. 
Figure 9. Controlling for NBER recessions

Defense news shocks

$\underline{\text { High private debt state versus neutral state }}$

Gov. spending
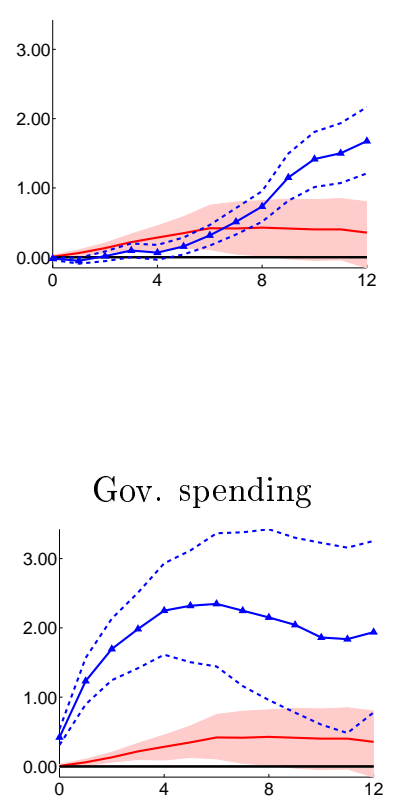

Gov. spending

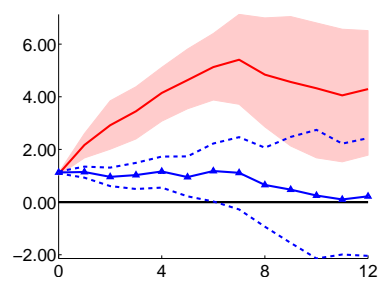

GDP

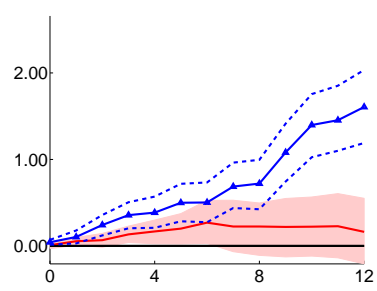

Consumption

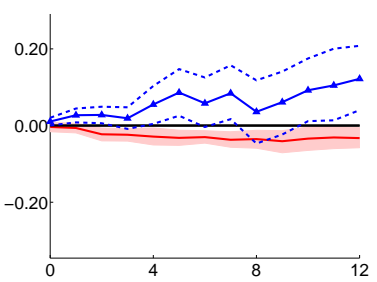

Investment

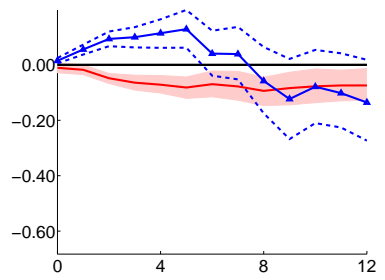

NBER recessions versus neutral state
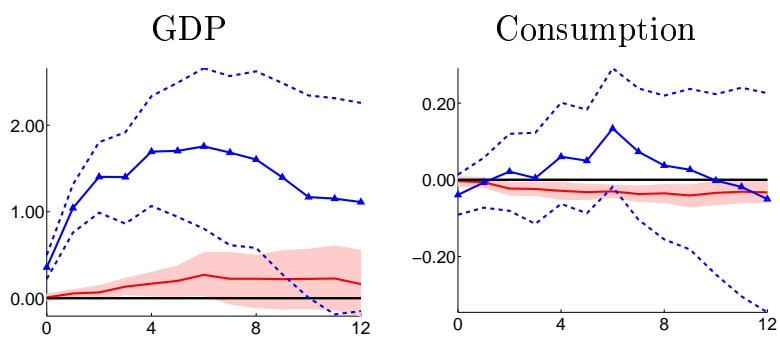

\section{TVP-VAR shocks}

$\underline{\text { High private debt state versus neutral state }}$
GDP

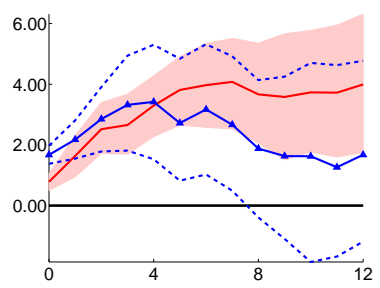

Consumption

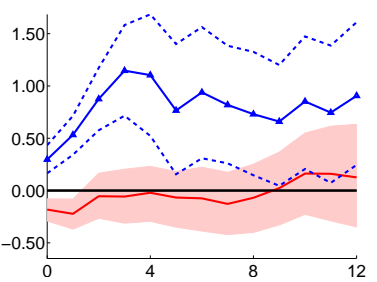

Investment

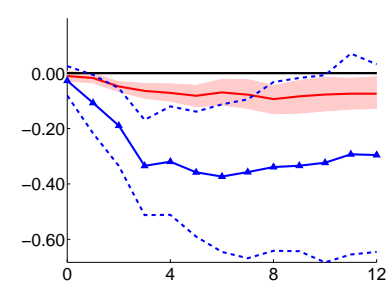

NBER recessions versus neutral state
Gov. spending

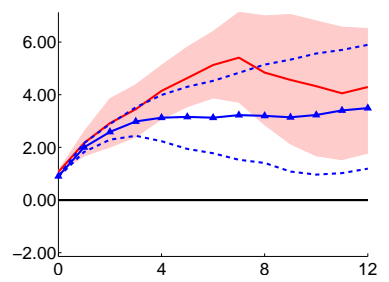

GDP

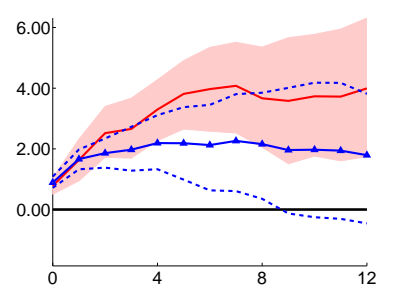

Consumption

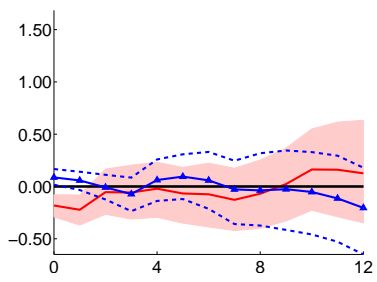

Investment

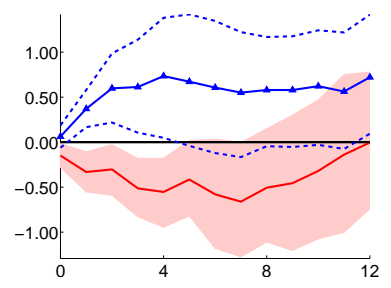

Investment

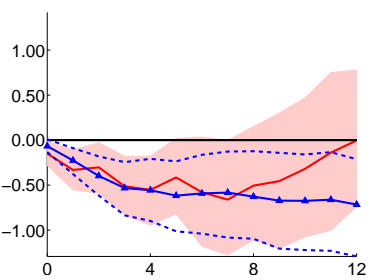


Figure 10. Controlling for the Zero Lower Bound

Defense news shocks

High private debt state versus neutral state

Gov. spending

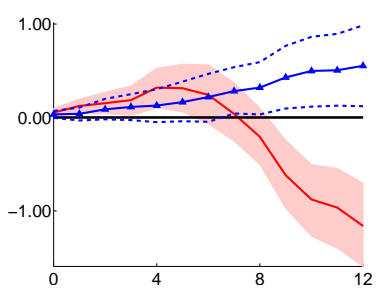

Gov. spending

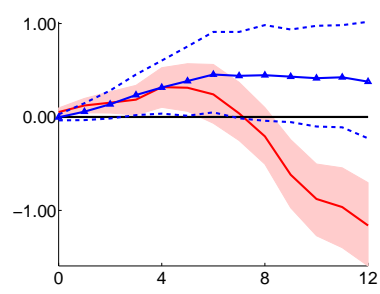

Gov. spending

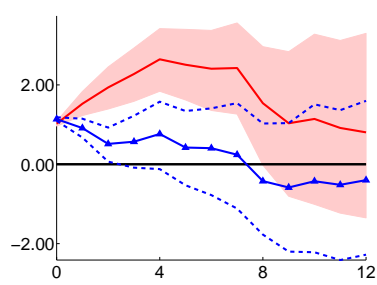

Gov. spending

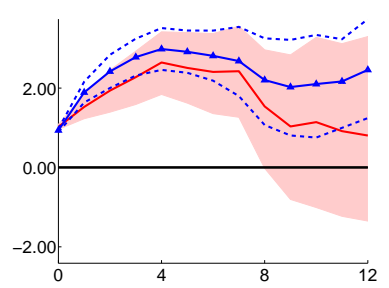

GDP

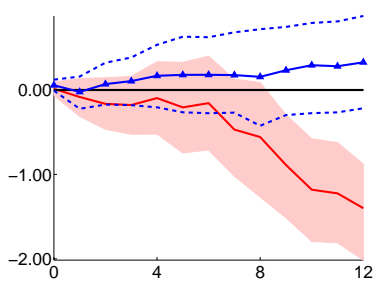

Zero Lower Bound versus neutral state

GDP

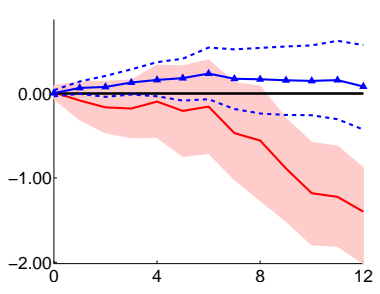

Consumption

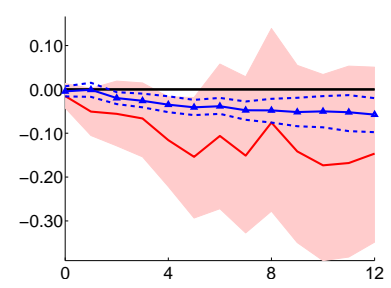

TVP-VAR shocks

High private debt state versus neutral state
GDP

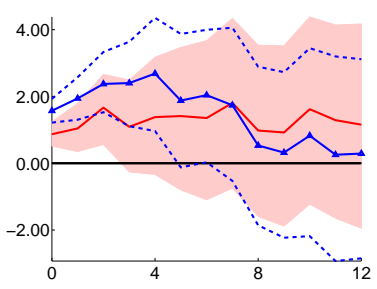

Consumption

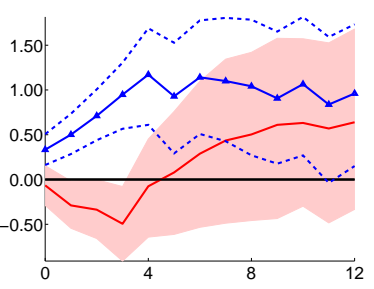

Investment

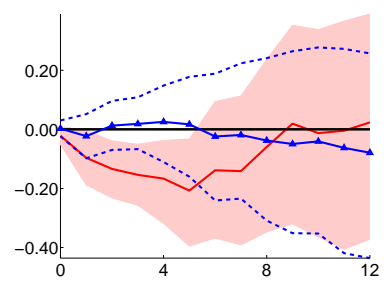

Investment

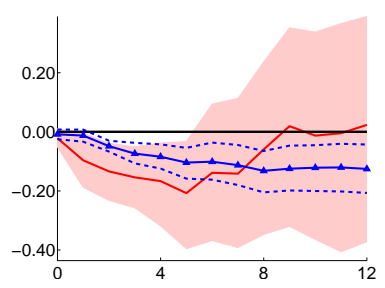

Investment

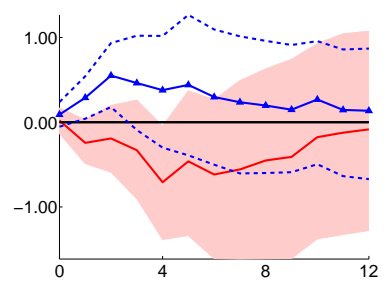

Zero Lower Bound versus neutral state

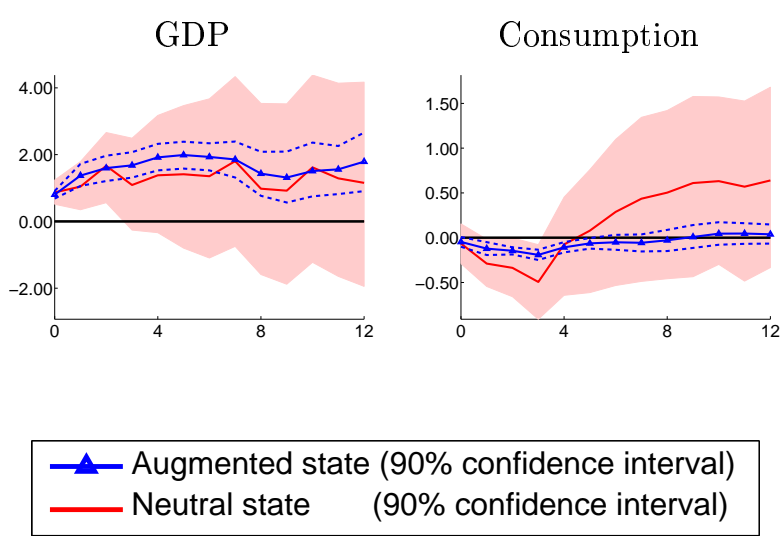

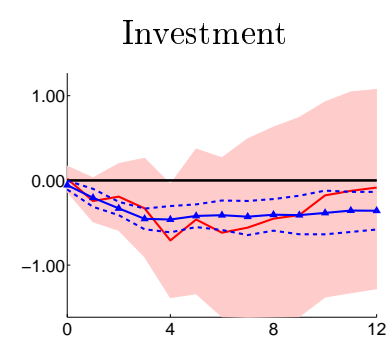




\section{Figure 11. Controlling for government debt overhang}

\section{Defense news shocks}

High private debt state versus neutral state

Gov. spending

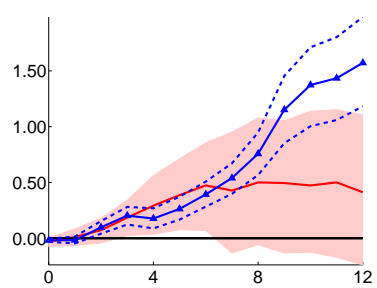

GDP

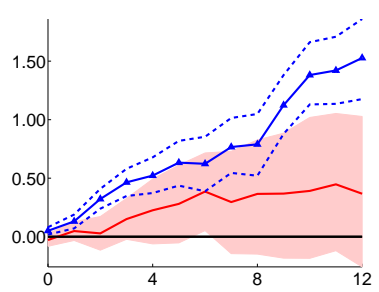

Consumption

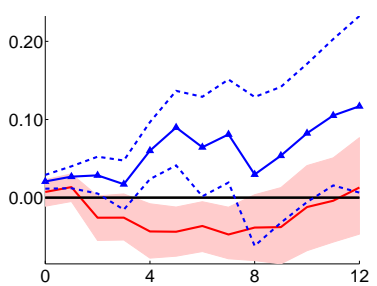

Investment

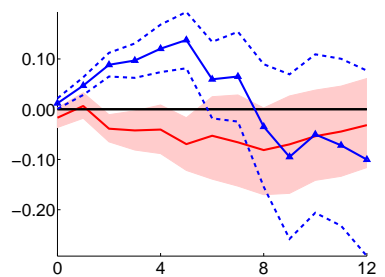

High government debt state versus neutral state

Gov. spending

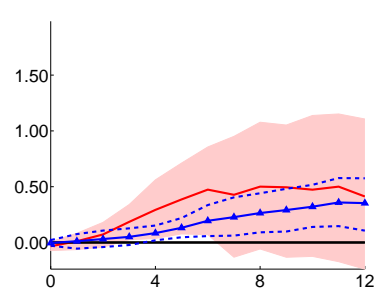

Gov. spending

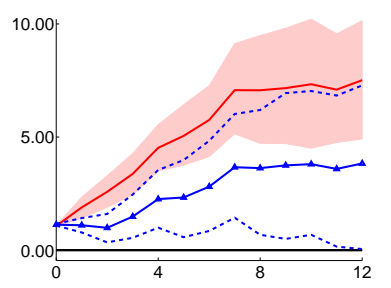

GDP

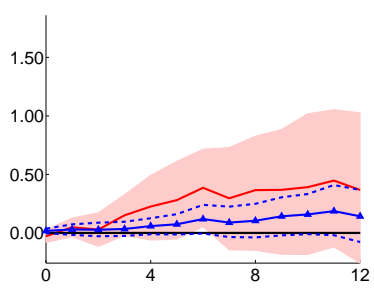

TVP-VAR shocks

High private debt state versus neutral state

GDP

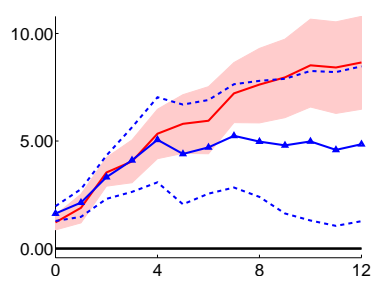

Consumption

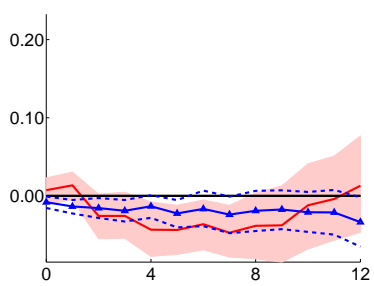

Consumption

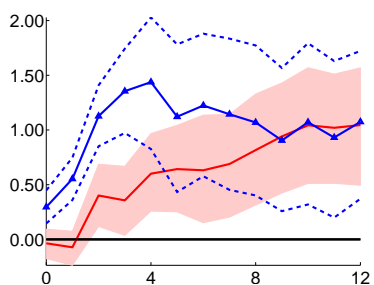

Investment

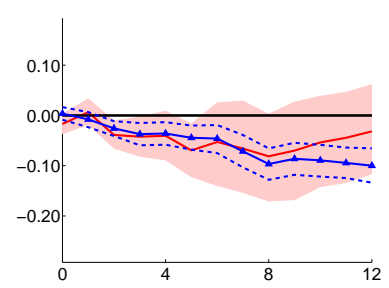

High government debt state versus neutral state

Gov. spending

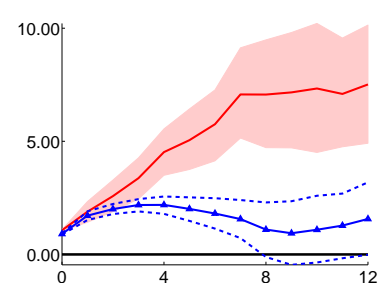

GDP

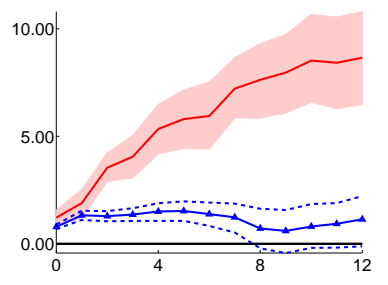

Investment

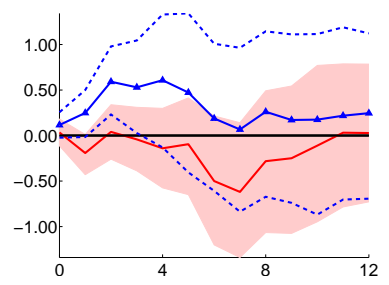

Consumption

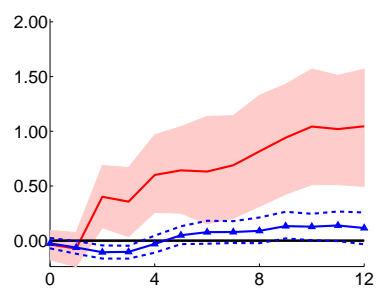

Investment

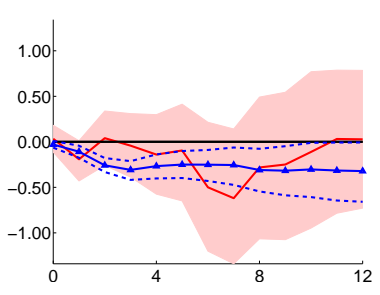

- Augmented state (90\% confidence interval) Neutral state (90\% confidence interval) 
Table 1. Government spending multipliers: the linear case

\begin{tabular}{r|c|c}
\hline \hline Horizon & Defense news shocks & TVP-VAR shocks \\
\hline $1^{\text {st }}$ year & 0.74 & 0.69 \\
& {$[0.441 .21]$} & {$[0.570 .81]$} \\
$2^{\text {nd }}$ year & 0.71 & 0.68 \\
& {$[0.491 .00]$} & {$[0.570 .83]$} \\
$3^{\text {rd }}$ year & 0.73 & 0.68 \\
& {$[0.540 .98]$} & {$[0.560 .80]$} \\
\hline \hline
\end{tabular}

Note: cumulative multipliers are based on point estimates shown in the figures; 5 th and 95 th percentiles between brackets are based on Monte Carlo simulations.

Table 2. Government spending multipliers in high private debt and low private debt states

\begin{tabular}{|c|c|c|c|c|c|c|}
\hline \multirow[b]{2}{*}{ Horizon } & \multicolumn{3}{|c|}{ Defense news shocks } & \multicolumn{3}{|c|}{ TVP-VAR shocks } \\
\hline & High debt & Low debt & High-Low & High debt & Low debt & High-Low \\
\hline \multirow[t]{2}{*}{$1^{\text {st }}$ year } & 3.86 & 0.70 & 3.16 & 2.65 & 0.70 & 1.96 \\
\hline & {$\left[\begin{array}{lll}2.87 & 5.21\end{array}\right]$} & {$\left[\begin{array}{ll}0.40 & 1.25\end{array}\right]$} & {$[2.034 .51]$} & {$\left[\begin{array}{lll}1.94 & 3.51\end{array}\right]$} & {$\left[\begin{array}{ll}0.61 & 0.79\end{array}\right]$} & {$\left[\begin{array}{ll}1.25 & 2.85\end{array}\right]$} \\
\hline \multirow[t]{2}{*}{$2^{\text {nd }}$ year } & 2.05 & 0.62 & 1.43 & 3.93 & 0.69 & 3.24 \\
\hline & {$\left[\begin{array}{ll}1.71 & 2.43\end{array}\right]$} & {$\left[\begin{array}{ll}0.38 & 0.97\end{array}\right]$} & {$\left[\begin{array}{ll}0.92 & 1.88\end{array}\right]$} & {$\left[\begin{array}{lll}2.65 & 5.89\end{array}\right]$} & {$\left[\begin{array}{ll}0.60 & 0.79\end{array}\right]$} & {$\left[\begin{array}{ll}1.94 & 5.21]\end{array}\right.$} \\
\hline \multirow[t]{2}{*}{$3^{r d}$ year } & 1.22 & 0.55 & 0.67 & 3.53 & 0.67 & 2.86 \\
\hline & {$\left[\begin{array}{ll}1.05 & 1.42\end{array}\right]$} & {$\left[\begin{array}{lll}0.34 & 0.82\end{array}\right]$} & {$\left[\begin{array}{lll}0.34 & 0.97\end{array}\right]$} & {$\left[\begin{array}{lll}2.07 & 7.21\end{array}\right]$} & {$\left[\begin{array}{lll}0.59 & 0.76\end{array}\right]$} & {$\left[\begin{array}{lll}1.37 & 6.47]\end{array}\right.$} \\
\hline
\end{tabular}

Note: cumulative multipliers are based on point estimates shown in the figures; 5 th and 95th percentiles between brackets are based on Monte Carlo simulations.

Table 3. Government spending multipliers in high private debt and low private debt states: 1947Q1-2013Q4

\begin{tabular}{c|ccc|ccc}
\hline \hline & \multicolumn{3}{|c|}{ Defense news shocks } & \multicolumn{3}{c}{ TVP-VAR shocks } \\
\hline \multirow{2}{*}{ Horizon } & High debt & Low debt & High-Low & High debt & Low debt & High-Low \\
\hline \multirow{2}{*}{$1^{\text {st }}$ year } & 1.03 & 0.28 & 0.76 & 1.71 & 0.56 & 1.15 \\
& {$[-0.602 .71]$} & {$[-0.030 .60]$} & {$[-0.892 .52]$} & {$[1.112 .31]$} & {$[0.270 .87]$} & {$[0.481 .81]$} \\
$2^{\text {nd }}$ year & 1.59 & 0.17 & 1.42 & 1.84 & 0.30 & 1.54 \\
& {$[0.512 .76]$} & {$[-0.030 .38]$} & {$[0.302 .60]$} & {$[1.222 .46]$} & {$[0.040 .56]$} & {$[0.882 .27]$} \\
$3^{\text {rd }}$ year & 2.21 & 0.18 & 2.03 & 1.64 & 0.32 & 1.32 \\
& {$[1.253 .18]$} & {$[-0.040 .40]$} & {$[1.043 .01]$} & {$[1.122 .19]$} & {$[0.090 .59]$} & {$[0.691 .91]$} \\
\hline \hline
\end{tabular}

Note: cumulative multipliers are based on point estimates shown in the figures; 5 th and 95th percentiles between brackets are based on Monte Carlo simulations. 
Table 4. Government spending multipliers: augmented state-dependent models

\section{Business cycle}

\begin{tabular}{|c|c|c|c|c|c|c|c|c|c|c|}
\hline \multirow{3}{*}{ Horizon } & \multicolumn{5}{|c|}{ Defense news shocks } & \multicolumn{5}{|c|}{ TVP-VAR shocks } \\
\hline & \multirow{2}{*}{$\frac{\text { Neutral }}{\text { (a) }}$} & \multirow{2}{*}{$\frac{\text { High-debt }}{\text { (b) }}$} & \multirow{2}{*}{$\frac{\text { Recessions }}{\text { (c) }}$} & \multicolumn{2}{|c|}{ Differences } & \multirow{2}{*}{$\frac{\text { Neutral }}{\text { (a) }}$} & \multirow{2}{*}{$\begin{array}{c}\text { High-debt } \\
\text { (b) }\end{array}$} & \multirow{2}{*}{$\frac{\text { Recessions }}{\text { (c) }}$} & \multicolumn{2}{|c|}{ Differences } \\
\hline & & & & (b)-(a) & $(\mathrm{c})-(\mathrm{a})$ & & & & (b)-(a) & $(\mathrm{c})-(\mathrm{a})$ \\
\hline \multirow[t]{2}{*}{$1^{s t}$ year } & 0.63 & 17.69 & 0.79 & 17.05 & 0.16 & 0.79 & 2.36 & 0.75 & 1.57 & -0.04 \\
\hline & {$\left[\begin{array}{ll}0.30 & 1.15\end{array}\right]$} & {$\left[\begin{array}{lll}-61.39 & 65.28\end{array}\right]$} & {$\left[\begin{array}{ll}0.63 & 0.98\end{array}\right]$} & {$\left[\begin{array}{lll}-62.18 & 64.58\end{array}\right]$} & {$\left[\begin{array}{ll}-0.41 & 0.57\end{array}\right]$} & {$\left[\begin{array}{ll}0.62 & 1.01\end{array}\right]$} & {$\left[\begin{array}{lll}1.85 & 3.00\end{array}\right]$} & {$\left[\begin{array}{ll}0.64 & 0.89\end{array}\right]$} & {$\left[\begin{array}{ll}1.09 & 2.14\end{array}\right]$} & {$\left[\begin{array}{ll}-0.29 & 0.19\end{array}\right]$} \\
\hline \multirow[t]{2}{*}{$2^{\text {nd }}$ year } & 0.60 & 2.59 & 0.76 & 1.99 & 0.16 & 0.79 & 2.54 & 0.72 & 1.75 & -0.07 \\
\hline & {$\left[\begin{array}{ll}0.35 & 0.99\end{array}\right]$} & {$\left[\begin{array}{ll}1.86 & 3.82\end{array}\right]$} & {$\left[\begin{array}{ll}0.60 & 0.93\end{array}\right]$} & {$\left[\begin{array}{ll}1.23 & 3.09\end{array}\right]$} & {$\left[\begin{array}{ll}-0.32 & 0.50\end{array}\right]$} & {$\left[\begin{array}{ll}0.67 & 0.93\end{array}\right]$} & {$\left[\begin{array}{ll}1.89 & 3.57\end{array}\right]$} & {$\left[\begin{array}{ll}0.56 & 0.89\end{array}\right]$} & [1.14 2.74] & {$\left[\begin{array}{ll}-0.28 & 0.14\end{array}\right]$} \\
\hline \multirow[t]{2}{*}{$3^{r d}$ year } & 0.57 & 1.27 & 0.73 & 0.70 & 0.16 & 0.80 & 2.80 & 0.68 & 2.00 & -0.12 \\
\hline & {$\left[\begin{array}{ll}0.33 & 0.95\end{array}\right]$} & {$\left[\begin{array}{ll}1.06 & 1.51\end{array}\right]$} & {$\left[\begin{array}{ll}0.57 & 0.92\end{array}\right]$} & {$\left[\begin{array}{ll}0.30 & 1.02\end{array}\right]$} & {$\left[\begin{array}{ll}-0.35 & 0.55\end{array}\right]$} & {$\left[\begin{array}{ll}0.67 & 0.95\end{array}\right]$} & {$\left[\begin{array}{lll}1.77 & 5.43\end{array}\right]$} & {$\left[\begin{array}{ll}0.50 & 0.88\end{array}\right]$} & {$\left[\begin{array}{ll}0.96 & 4.62\end{array}\right]$} & {$\left[\begin{array}{lll}-0.34 & 0.09\end{array}\right]$} \\
\hline
\end{tabular}

\section{Zero Lower Bound}

\begin{tabular}{|c|c|c|c|c|c|c|c|c|c|c|}
\hline \multirow{3}{*}{ Horizon } & \multicolumn{5}{|c|}{ Defense news shocks } & \multicolumn{5}{|c|}{ TVP-VAR shocks } \\
\hline & \multirow{2}{*}{$\frac{\text { Neutral }}{\text { (a) }}$} & \multirow{2}{*}{$\begin{array}{c}\text { High-debt } \\
\text { (b) }\end{array}$} & \multirow{2}{*}{$\begin{array}{c}\text { ZLB } \\
\text { (c) }\end{array}$} & \multicolumn{2}{|c|}{ Differences } & \multirow{2}{*}{$\begin{array}{c}\text { Neutral } \\
\text { (a) }\end{array}$} & \multirow{2}{*}{$\begin{array}{c}\text { High-debt } \\
\text { (b) }\end{array}$} & \multirow{2}{*}{$\begin{array}{c}\text { ZLB } \\
\text { (c) }\end{array}$} & \multicolumn{2}{|c|}{ Differences } \\
\hline & & & & (b)-(a) & (c)-(a) & & & & (b)-(a) & (c)-(a) \\
\hline \multirow[t]{2}{*}{$1^{s t}$ year } & -0.80 & 0.77 & 0.66 & 1.57 & 1.46 & 0.69 & 2.65 & 0.68 & 1.96 & -0.01 \\
\hline & {$\left[\begin{array}{ll}-2.25 & 0.18\end{array}\right]$} & {$\left[\begin{array}{ll}-1.13 & 3.22\end{array}\right]$} & {$\left[\begin{array}{lll}0.16 & 2.22\end{array}\right]$} & {$\left[\begin{array}{lll}0.52 & 3.93\end{array}\right]$} & {$\left[\begin{array}{lll}0.33 & 3.95\end{array}\right]$} & {$\left[\begin{array}{lll}0.40 & 1.00\end{array}\right]$} & {$\left[\begin{array}{lll}1.90 & 3.77\end{array}\right]$} & {$\left[\begin{array}{ll}0.16 & 2.22\end{array}\right]$} & {$\left[\begin{array}{ll}1.23 & 3.02\end{array}\right]$} & {$\left[\begin{array}{ll}-0.31 & 0.27\end{array}\right]$} \\
\hline \multirow[t]{2}{*}{$2^{\text {nd }}$ year } & -0.94 & 0.86 & 0.51 & 1.79 & 1.45 & 0.63 & 3.35 & 0.68 & 2.72 & 0.04 \\
\hline & {$\left[\begin{array}{lll}-2.10 & -0.13]\end{array}\right]$} & {$\left[\begin{array}{ll}-0.07 & 2.22\end{array}\right]$} & {$\left[\begin{array}{ll}0.21 & 1.04\end{array}\right]$} & {$\left[\begin{array}{llll}1.14 & 3.13\end{array}\right]$} & {$\left[\begin{array}{ll}0.60 & 2.79\end{array}\right]$} & {$\left[\begin{array}{lll}0.34 & 0.96\end{array}\right]$} & {$\left[\begin{array}{lll}2.05 & 6.64\end{array}\right]$} & {$\left[\begin{array}{ll}0.60 & 0.76\end{array}\right]$} & {$\left[\begin{array}{lll}1.48 & 5.87\end{array}\right]$} & {$\left[\begin{array}{lll}-0.29 & 0.33\end{array}\right]$} \\
\hline \multirow[t]{2}{*}{$3^{\text {rd }}$ year } & 4.18 & 0.67 & 0.45 & -3.51 & -3.74 & 0.72 & 6.17 & 0.68 & 5.45 & -0.04 \\
\hline & {$\left[\begin{array}{lll}2.04 & 15.12\end{array}\right]$} & {$\left[\begin{array}{ll}0.15 & 1.30\end{array}\right]$} & {$\left[\begin{array}{ll}0.18 & 0.85\end{array}\right]$} & [-14.90 -0.88] & {$[-14.68-1.38]$} & {$\left[\begin{array}{ll}0.38 & 1.14\end{array}\right]$} & {$\left[\begin{array}{lll}-20.99 & 31.94\end{array}\right]$} & {$\left[\begin{array}{ll}0.59 & 0.79\end{array}\right]$} & {$\left[\begin{array}{lll}-21.77 & 31.09\end{array}\right]$} & {$\left[\begin{array}{ll}-0.46 & 0.30\end{array}\right]$} \\
\hline
\end{tabular}

\section{Government debt overhang}

\begin{tabular}{|c|c|c|c|c|c|c|c|c|c|c|}
\hline \multirow{3}{*}{ Horizon } & \multicolumn{5}{|c|}{ Defense news shocks } & \multicolumn{5}{|c|}{ TVP-VAR shocks } \\
\hline & \multirow{2}{*}{$\begin{array}{c}\text { Neutral } \\
\text { (a) }\end{array}$} & \multirow{2}{*}{$\begin{array}{c}\text { High-debt } \\
\text { (b) }\end{array}$} & \multirow{2}{*}{$\frac{\text { Gov. debt }}{\text { (c) }}$} & \multicolumn{2}{|c|}{ Differences } & \multirow{2}{*}{$\begin{array}{c}\text { Neutral } \\
\text { (a) }\end{array}$} & \multirow{2}{*}{$\begin{array}{c}\text { High-debt } \\
\text { (b) }\end{array}$} & \multirow{2}{*}{$\frac{\text { Gov. debt }}{\text { (c) }}$} & \multicolumn{2}{|c|}{ Differences } \\
\hline & & & & (b)-(a) & (c)-(a) & & & & (b)-(a) & (c)-(a) \\
\hline \multirow[t]{2}{*}{$1^{s t}$ year } & 0.85 & 3.67 & 1.24 & 2.81 & 0.38 & 1.20 & 2.38 & 0.70 & 1.18 & -0.50 \\
\hline & {$\left[\begin{array}{lll}-0.67 & 3.67\end{array}\right]$} & {$\left[\begin{array}{lll}2.49 & 6.36\end{array}\right]$} & {$[-5.106 .50]$} & {$\left[\begin{array}{lll}0.32 & 6.69\end{array}\right]$} & {$\left[\begin{array}{lll}-7.91 & 7.32\end{array}\right]$} & {$\left[\begin{array}{ll}1.00 & 1.47\end{array}\right]$} & {$\left[\begin{array}{lll}1.78 & 3.37\end{array}\right]$} & {$\left[\begin{array}{ll}0.63 & 0.78\end{array}\right]$} & {$\left[\begin{array}{lll}0.67 & 2.00\end{array}\right]$} & {$[-0.76-0.29]$} \\
\hline \multirow[t]{2}{*}{$2^{\text {nd }}$ year } & 0.77 & 2.15 & 0.62 & 1.38 & -0.15 & 1.12 & 1.94 & 0.72 & 0.82 & -0.39 \\
\hline & {$\left[\begin{array}{lll}0.34 & 1.52\end{array}\right]$} & {$\left[\begin{array}{lll}1.75 & 2.62\end{array}\right]$} & {$\left[\begin{array}{lll}0.29 & 1.16\end{array}\right]$} & {$\left[\begin{array}{ll}0.72 & 1.87\end{array}\right]$} & {$\left[\begin{array}{ll}-0.79 & 0.34\end{array}\right]$} & {$\left[\begin{array}{ll}0.98 & 1.28\end{array}\right]$} & {$\left[\begin{array}{lll}1.46 & 2.65\end{array}\right]$} & {$\left[\begin{array}{ll}0.62 & 0.83\end{array}\right]$} & {$\left[\begin{array}{lll}0.41 & 1.44\end{array}\right]$} & {$[-0.59-0.20]$} \\
\hline \multirow[t]{2}{*}{$3^{\text {rd }}$ year } & 0.78 & 1.30 & 0.53 & 0.51 & -0.25 & 1.13 & 1.64 & 0.72 & 0.51 & -0.41 \\
\hline & {$\left[\begin{array}{lll}0.40 & 1.48\end{array}\right]$} & {$\left[\begin{array}{ll}1.13 & 1.50\end{array}\right]$} & {$\left[\begin{array}{ll}0.31 & 0.81\end{array}\right]$} & {$\left[\begin{array}{lll}-0.17 & 0.93\end{array}\right]$} & {$\left[\begin{array}{lll}-0.87 & 0.10\end{array}\right]$} & {$\left[\begin{array}{ll}0.99 & 1.28\end{array}\right]$} & {$\left[\begin{array}{lll}1.24 & 2.26\end{array}\right]$} & {$\left[\begin{array}{lll}0.56 & 0.92\end{array}\right]$} & {$\left[\begin{array}{lll}0.13 & 1.06\end{array}\right]$} & {$[-0.64-0.16]$} \\
\hline
\end{tabular}

Note: cumulative multipliers are based on point estimates shown in the figures; 5 th and 95th percentiles between brackets are based on Monte Carlo simulations. 